\title{
Mikheil Cavakhişvili’nin “Suçsuz Abdullah” eserinin Türkçeye Tercümesinde kelime ve ifadeler
}

\section{Gül Mükerrem ÖZTÜRK¹}

\begin{abstract}
APA: Öztürk, G. M. (2020). Mikheil Cavakhişvili'nin "Suçsuz Abdullah" eserinin Türkçeye Tercümesinde kelime ve ifadeler. RumeliDE Dil ve Edebiyat Araştırmaları Dergisi, (18), 494-511. DOI: 10.2900o/rumelide.706230.
\end{abstract}

\section{Öz}

Ulusların tarih boyunca siyasi ve kültürel temaslarının yanı sıra çeşitli alanlardaki ilişkileri dilde de yansıma bulmuştur. Kültürel temasların dildeki yansımaları daha çok söz varlığı üzerine olmuştur. Bu çalışmada 20. yüzyılın en önemli yazarlarından biri olan Mikheil Cavahişvili’nin kaleme aldı̆̆ı Suçsuz Abdullah adlı eserinin 1925 ve 2011 yılı basımları ele alınacaktır. Eserlerde geçen kelime ve ifadelerin Türkçeye tercümesi, bu makalenin asıl konusunu oluşturmaktadır. İnceleme sırasında ilk olarak Gürcü Dili ve Edebiyatı tarihine kısaca değindikten sonra tarih boyunca Türk-Gürcü dil ilişkilerinden kısaca bahsedilecektir. Sonrasında yazarın yaşamı ve edebi kişiliği hakkında bilgi verilecek ve Suçsuz Abdullah adlı eser, tanıtılacaktır. Tüm bu veriler ışı̆̆ında 1988 yılında İbrahim Yavuz Goradze tarafından Türkçeye çevrilen Suçsuz Abdullah; 1925 yılında œ®๓nð১ / Droşa (Bayrak)

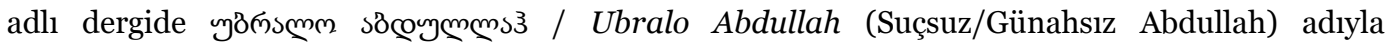

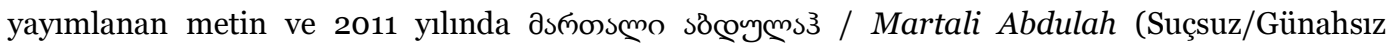
Abdullah) adıyla yayımlanan metinle karşılaştırılacaktır. Bu karşılaştırmada kaynak metinlerden seçilen kelime ve ifadelerin Türkçeye nasıl aktarıldığını tespit edeceğiz. Sonuç olarak, tespit ettiğimiz kelime ifadeler, eserin yazıldığı 20. yy. Türk-Gürcü ilişkilerinin kültürel boyutu dil malzemesi bakımından değerlendirilecektir. Bununla birlikte, kaynak metinlerdeki kültürel ifadelerin erek metine nasıl aktarıldığı da karşılaştırarak incelenmiştir. Böylece Türk-Gürcü ilişkilerinin kültürel alanda nasıl bir gelişim seyri izlediği ortaya konmuş olacaktır.

Anahtar kelimeler: Mikheil Cavahişvili, Suçsuz Abdula, karşılaştırma, Gürcü dili, kültür.

\section{Word and expression choice in the translation of Mikheil Cavahishvili's work titled "Suçsuz Abdullah" into Turkish}

\begin{abstract}
Throughout history, nations' relations in various fields, in addition to their political and cultural contacts, have been reflected in the language as well. The reflections of cultural interactions in the language were mostly on vocabulary. In this study, the 1925 and 2011 editions of the book titled Suçsuz Abdullah by Mikheil Cavahişvili, who was one of the most important writers of the 2oth century, will be discussed. The translation of words and expressions into Turkish is underlined in this study. During the examination, after the history of Georgian language and literature will be briefly mentioned, the history of Turkish-Georgian language relations will be briefly stated. Following brief information about the life and literary personality of the author, the subject of the book titled Suçsuz

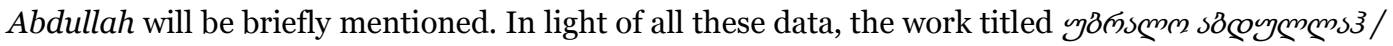
Ubralo Abdullah (Blameless/ innocent Abdullah) published in 1925 in the journal @๓næas / Droşa
\end{abstract}

1 Dr. Öğr. Üyesi, Recep Tayyip Erdoğan Üniversitesi, Fen Edebiyat Fakültesi, Gürcü Dili ve Edebiyatı Bölümü (Rize, Türkiye), gul.ozturk@erdogan.edu.tr, ORCID ID: 0000-0003-4730-6720 [Makale kayıt tarihi: 02.01.2020-kabul tarihi: 20.03.2020; DOI: 10.29000/rumelide.706230] 


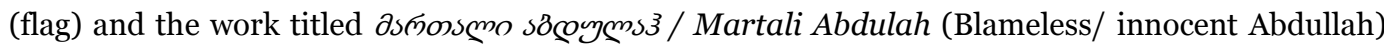
published in 2011 will be compared with the text titled "Suçsuz Abdullah" translated into Turkish by Yavuz Goradze in 1988. In this comparison, we will compare comparatively how the words and expressions selected from the source texts are transferred to Turkish. As a result, the words and expressions we have identified reveal the cultural aspects of the Turkish-Georgian relations while living with the Turks in the 2oth century when the work was written. How the culture items in the source texs are transferred to the target text is comparatively examined. In this way, this study shows us in which field relations between Georgians and Turks have developed.

Keywords: Mikheil Cavahişvili, Suçsuz Abdula, comparison, Georgian language, culture.

\section{Giriş}

Dünyadaki 14 resmi alfabeden biri olan Gürcü alfabesi, Gürcü kralı Parnavaz tarafından 3. yüzyılda geliştirilmiştir. "Gürcü alfabesine ait ilk eserler 5. yy.a aittir. Eski Gürcücenin en eski yazılı anıtı V. yüzyıldandır.” (Türk Ansiklopedisi, 1970: 54). Gürcüce, İberya-Kafkas dilleri arasında en çok konuşulan dil olma özeliğine sahiptir. "Her harf bir rakamı ifade etmektedir. Stralamaya göre ilk dokuz harf tekli rakamları (a/1, b/2, g/3 ...) ifade eder”. (Sağinadze, Peikrishvili, Çimke, 2015: 27). Bugünkü Gürcü alfabesi 5’i ünlü, 28’i ünsüz 33 harften oluşmaktadır.

Gürcü edebiyatı ise çok eski ve zengin bir edebiyat geleneğine sahiptir. Bu geleneğin temeli yaklaşık 1500

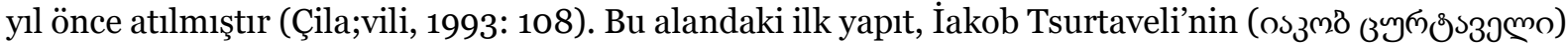

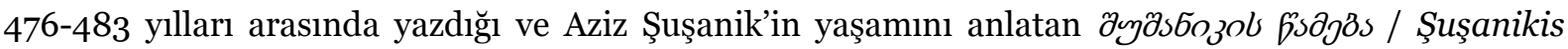

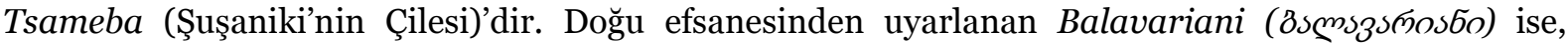
Gürcüceden Eski Yunancaya, Eski Yunancadan da Latinceye çevrilerek Orta Çağ Avrupası'na yayılmıştır. Gürcistan'ın en ünlü eğitim kurumlarından biri olan Gelati Akademisi'nden Gürcü filozof İoane Petritsi

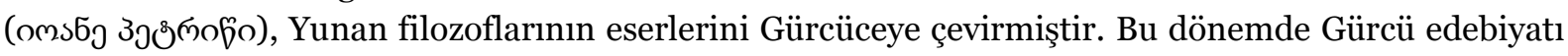
İran uygarlığı ile Bizans kültürünün etkisinde kalmış ve ilk tarihsel eserlerde bu dönemde ortaya

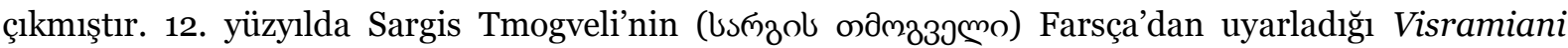

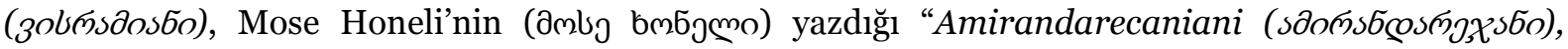
Çahruhadze'nin (Bsbmybssdg) Kraliçe Tamara ve kocası adına kaleme aldığı Tamariani (ossas๓os6o),

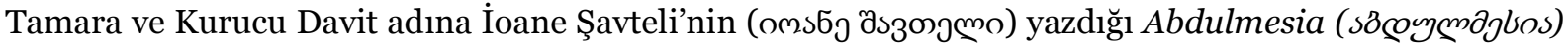
dönemin tanınmış eserleri arasındadır. Tamara döneminde yaşayan Şota Rustaveli'nin (סֻmos

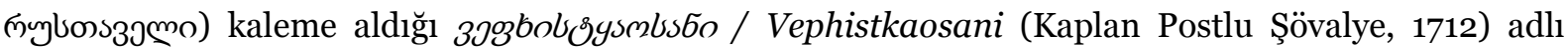
destan, Gürcü edebiyatının en ünlü yapıtıdır. Yaklaşık her dilden çevirisi bulunan eser, edebiyat bilimcilerinin dışında dilbilimcilerin ve tarihçilerin de ilgisini çekmiştir.

18. yüzyılda Gürcü edebiyatında bir canlanma görülmüştür. 18. yüzyllın ilk çeyreğinde Kral VI. Vahtang 1709 yllında Gürcistan'da ilk basım evini kurmuştur. Vephistkaosani adlı eser de 1712 yılında ilk kez

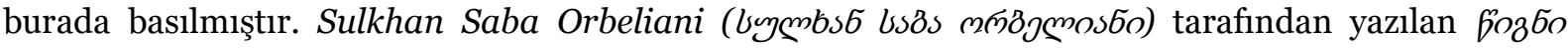

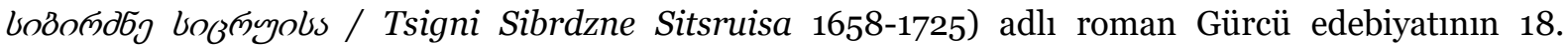

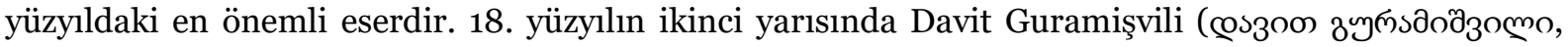

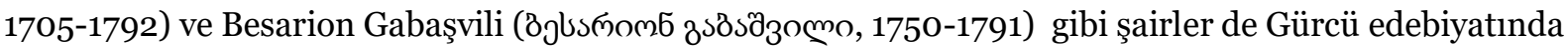
önemli izler bırakmışlardır. Bu şairler Gürcistan’ın feodal yapısına yönelik şiirlerini bu dönemde yazmışlardır. 
Word and expression choice in the translation of Mikheil Cavahishvili's work titled "Suçsuz Abdullah" into Turkish / G. M. Öztürk (pp. 494-511)

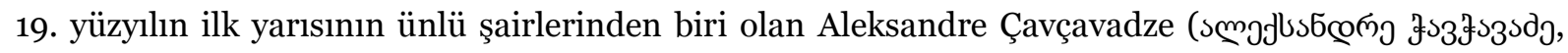
1786-1846) özgürlükçü şiirlerini bu dönemde yazmıştır. Dönemin diğer ünlü temsilcileri ise Grigol

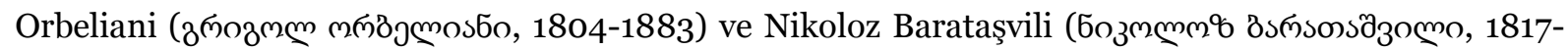

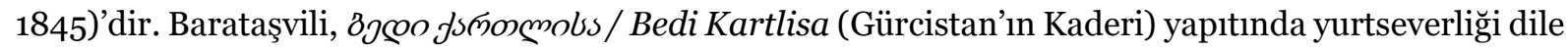
getirmiştir. Gürcü edebiyatı ve tiyatrosu alanında etkisini artıran diğer bilim adamı Giorgi Eristavi

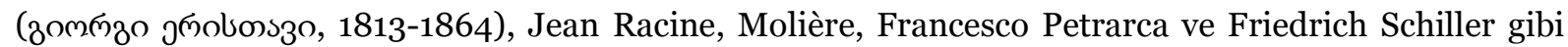
sanatçlların birçok eserini Gürcüceye çevirmiştir. Dönemin diğer önemli yazarlarından İlia Çavçavadze

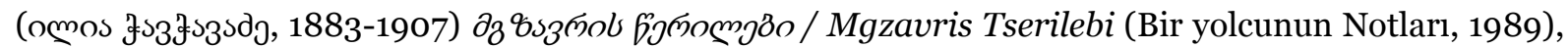

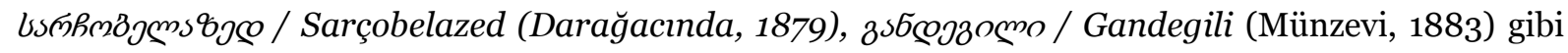
yapıtlarında Gürcü halkının özgürlük mücadelesini ve yurt sevgisini dile getirmiştir. İlia Çavçavadze ile birlikte Gürcü ulusal hareketinin ideolojik önderliğini yapan yakın arkadaşı Akaki Tsereteli (

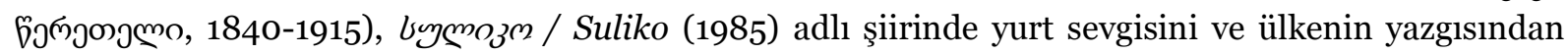
duyduğu acıları işlemiştir. Ayrıca şiirin yanı sıra düzyazılar ve oyunlar da yazmıştır. En ünlü düzyazı biyografisi eseri, Rjdo onsz̧scoslszsscmo / Çemi Tavgadasavali'dir. (Benim Maceram, 1894).

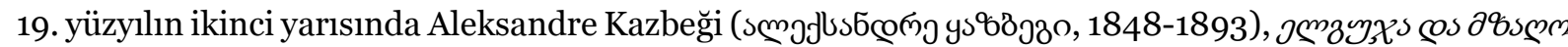

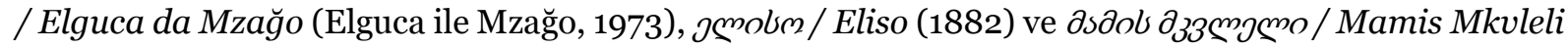
(Baba Katili, 1882) gibi öykülerinde dağ yaşamını ele almıştır. Dönemin şair ve yazarlarından Vaja

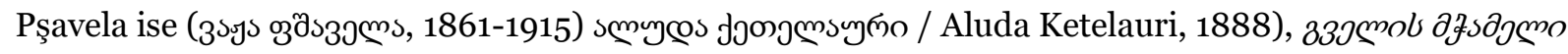
/ Gvelis Mçameli (Yılan Yiyici, 1901) gibi yapıtlarında temelde insan-doğa ilişkisini ve hümanizm

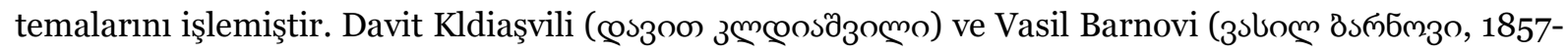
1934), edebi dönemin iki önemli temsilcileridir. Davit Kldiaşvili, soyluların yaşam biçimini, kadere karşı

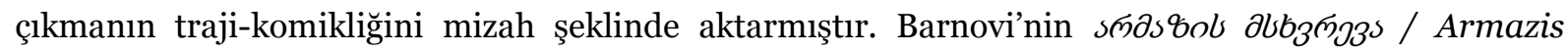
Mskhvreva (Armazi’nin Yıkımı, 1925) adlı romanı da dönemin önemli eserlerindendir.

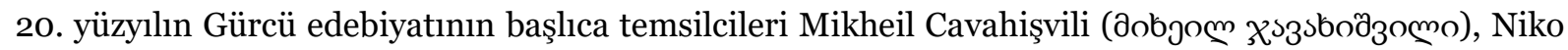

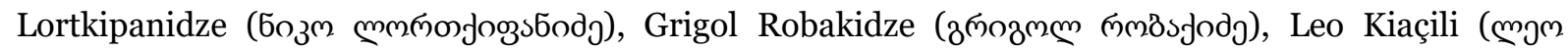

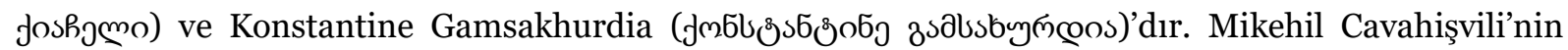

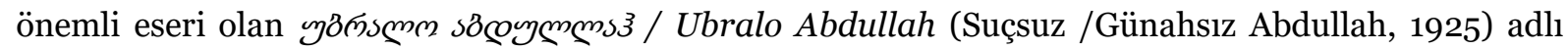
öyküsünde siyasal bürokrasinin kurbanı olan Müslüman bir adamı ustalıkla resmetmiştir. Ayrıca

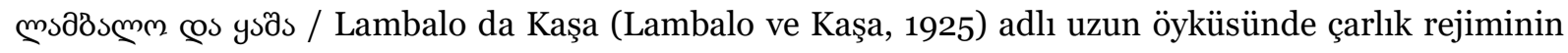
uygulamaları karşısında milliyetçi ve dinsel baskılara karşı çıkan Müslüman bir genci anlatmıştır.

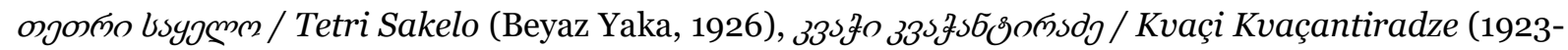

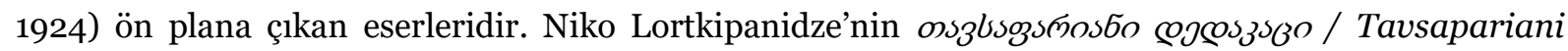

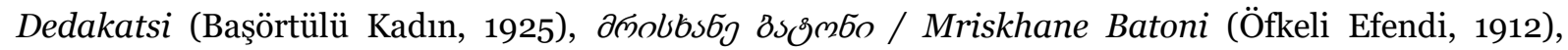

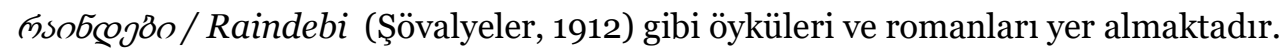

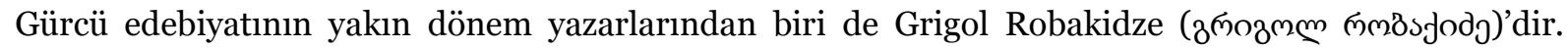

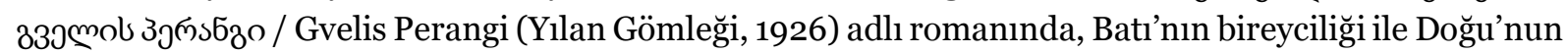
bütüncül ve kişilik üstü düşüncesi arasındaki çatışmayı eserlerinde ustaca işlemiştir. Sovyet dönemi Gürcü edebiyatının kurucularından biri olan Leo Kiaçeli (

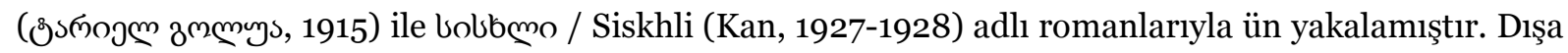
vurumculuktan ve Friedrich Nietzsche'nin düşüncelerinden etkilenen Konstantine Gamsahurdia

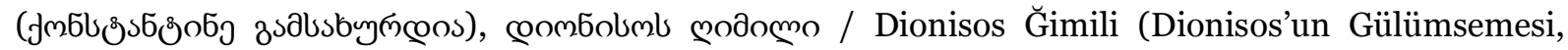

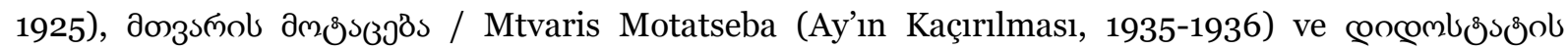

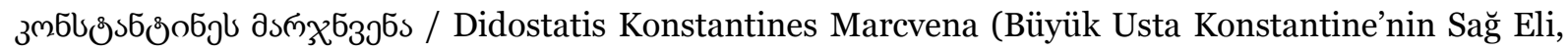
1939) adlı eserleriyle tanınmaktadır. 


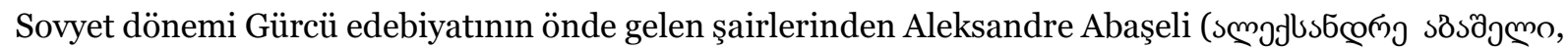
1884-1954), simgeci bir şair olarak yazmaya başlamıştır. d\%ol bo(̧omo / Mzis Sitsili (Güneşin Gülüşü,

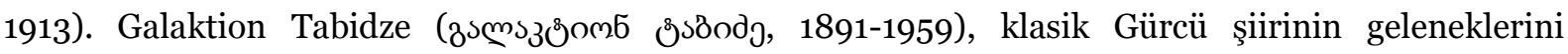

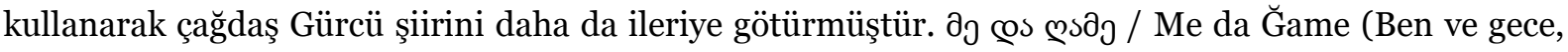

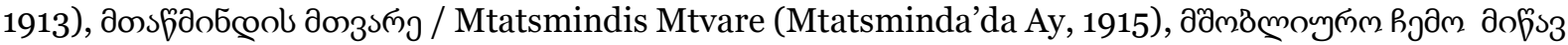
/ Mşobliuro Çemo Mitsav (Benim Anayurt Toprağım, 1941) gibi eserlerinde aşkı ve doğayı çeşitli yönleriyle ele alarak Gürcistan'ı konu edinmiştir. Halkın yaşanan olaylar karşısındaki duygu ve düşüncelerini yansitan Giorgi Leonidze (зопмдо мэмбодђ, 1897-1966), Gürcü edebiyatının önde gelen toplumcu şairlerinden biridir. Şairin 5 sð̊3

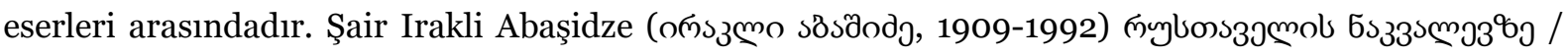
Rustavelis Nakvalevze (Rustaveli'nin İzinde, 1959) adlı yapıtında duygu ve düşüncelerini ortaya

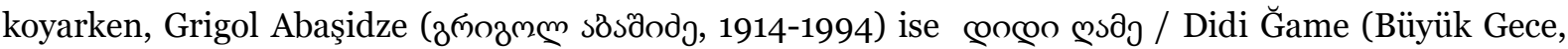
1963) ve msð̊s mgஞু / Laşalera (Kök, 1977) gibi şiirlerinde ülkesine ve halkına bağlılı̆̆ını dile getirmiştir.

Gürcü edebiyatının 1950'li yılların sonunda farklı bakış açılarına sahip şair ve yazarlar göze çarpmaktadır. 1930 ve 1940'lı yılların edebiyat anlayışını yıkmışlardır. Bu dönemde Guram Rçeulişvili

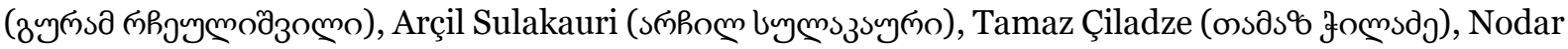

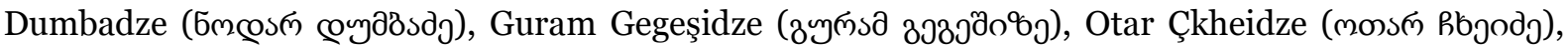

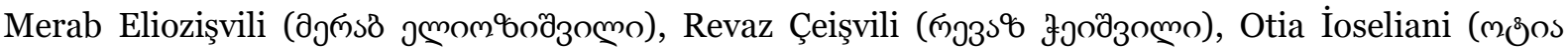

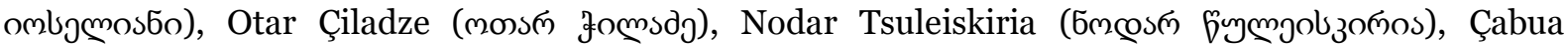

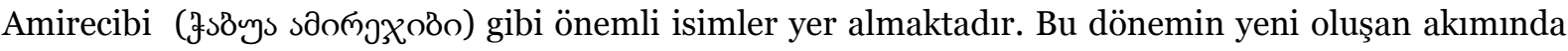

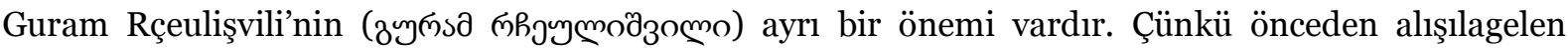

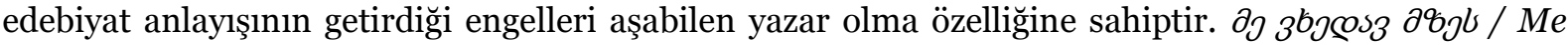

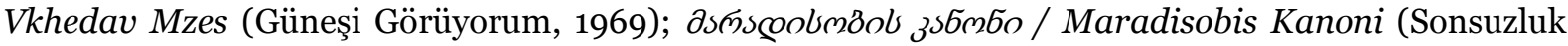

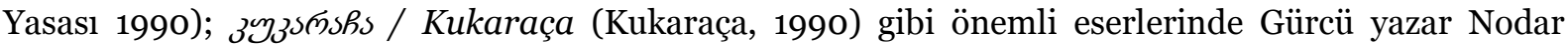

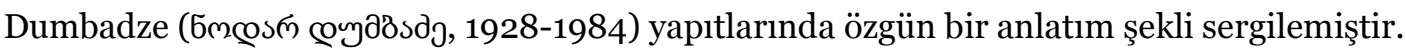

Gürcü edebiyatı 1970'li yıllarda Gürcü halkının geleneklerinin değiştirilmesine karşı durulmuştur.

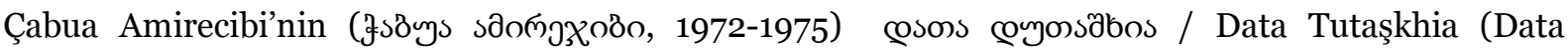
Tutaşkhia, 1978) adlı romanı bu durumu sergileyen önemli bir eserdir.

\section{Tarih boyunca Türk-Gürcü dil ilişkileri}

Türk - Gürcü ilişkilerinin çok eskilere dayandığı bilinmektedir. Bu ilişkilerin daha çok birbirlerinin dillerini öğrenmek yoluyla gerçekleşmiştir. Bu konu, Gürcistan'da önem verilen bir husustur. Bu bağlamda Gürcü okuyucular, Türk edebiyatı ile erkenden tanışmıştır. Bu yakınlık, Tiflis Devlet Üniversitesi ve Doğu Bilimleri Enstitüsündeki tanınmış Türkologların hizmetleri sayesinde ortaya çlkmıştır (Öztürk, 2015: 779). Bunun dışında Gürcistan Bilimler Akademisinin Edebiyat, Tarih ve El Yazmaları Enstitülerinde, Tiflis Pedagoji Üniversitesi’nde, Batum, Kutaisi ve Akhaltsikhe (Ahıska) Devlet Üniversitelerinde, Batum ve Tiflis Müzelerinde Türkoloji ile alakalı konular da araştırılıp incelenmektedir.

Türkçenin Gürcistan'da konuşulması eski zamanlara dayanmakta ve eski dönem Gürcistan'da fsøonભnol obmзウ̆g8s / Kartlis Tshovreba (Gürcü Yaşamı) adlı Gürcüce kaynağa göre altı dilin konuşulduğu belirtilmektedir. Thomson'a göre bu dillerden birisi de Hazarların konuştukları Türkçedir (Thomson, 2006: 112). Tiflis Devlet Üniversitesi’nde Türkolog Sergi Cikia sayesinde Türkoloji bölümü kurulmuştur. Türkolog Sergi Cikia, Türkiye'de bulunmuş; Mehmed Fuad Köprülü’den, Ahmed Hamdi Tanpınar'dan 
Word and expression choice in the translation of Mikheil Cavahishvili's work titled "Suçsuz Abdullah" into Turkish / G. M. Öztürk (pp. 494-511)

dersler almıştır. Edindiği bilgileri Gürcistan'da öğrencilerine aktararak Türkolojiyi ileri seviyeye ulaştırmayı amaçlamıştır. Sergi Cikia, her iki ülkenin tarihini, kültürünü, edebiyatını, ekonomik ilişkilerini Osmanlı Türkçesi belgelerde araştırdıktan sonra Gürcüceye tercüme etmiştir. Gürcistan'daki Türkologlar, ayrıca Gürcistan'da yaşayan ve Türkçe konuşan halkların dilleri üzerine incelemelerde bulunmuşlardır. Bu incelemelerde büyük katkısı bulunan Sergi Cikia, geçmiş yüzyılın 3o'lu yıllarında Meskheti bölgesinde (Güney Gürcistan) yaşayan Türkçe konuşan nüfusun ağız örneklerini incelemiştir (Abuladze, 2004: 541). "Gürcü edebiyatının Türk okuyucularla tanışmasını ele alırsak Gürcü edebiyatı Türk toplumuna daha geç dönemlerde erişebilme firsatı bulmuştur. 1940 yılında Niyazi Ahmet Banoğlu, Gürcü edebiyatıyla ilgilenmiş fakat onun bu çabaları yeteri kadar ilgi görmemiştir. Gürcü edebiyatıyla ciddi temaslar 1960 yllından itibaren baş göstermiştir" (Öztürk, 2015: 776). Bugün Türk - Gürcü edebi ilişkilerini geliştirme girişimi Mamuli Dergisiyle başlamıştır. Mamuli Dergisi Türkiye'de yayınlanan, Türkiye'de yaşayan Gürcüler ve Gürcistan'la ilgilenen Türkler için yayınlanan bir dergidir. İstanbul'da 1997-1998 yıllarında iki dilli Türkçe-Gürcüce olarak beş sayısı yayınlanmıştır. Dergide Gürcistan ve Kafkasya'ya ait yazılar ve makaleler yer almaktadır. Mamuli Dergisi’nden sonra Türkiye'de yayınlanan diğer bir dergi Çveneburi Dergisidir. Çveneburi Dergisi; hem şair, hem yazar hem de tercüman için Gürcistan ile bağlantı kurma işlevi görmektedir. "Çveneburi” ismi "bizden“ anlamındadır. Gürcistan’da yaşayan Müslüman Gürcülere verilen isimdir. Buradan hareketle derginin başlı̆̆ı bu şekilde oluşmuştur. Derginin içeriği çok kapsamlıdır. Okuyucular Gürcü edebiyatıyla, Gürcü halk bilimiyle, sanatıyla, kültürüyle, tarihiyle, etnografyasıyla, sosyal ve ekonomik durumuyla ilgili bilgilerle karşılaşmaktadır (Öztürk, 2015: 777). İlk sayısı 1977 yılında Türkçe olarak ve Türkiye’de yaşayan Gürcü kültür temsilcileri önderliğinde Stockholm’de yayınlanmıştır. Derginin editörü Ahmet Özkan Melaşvili’dir (Öztürk, 2015: 777). Çveneburi Dergisinden sonra Pirosmani Dergisi Türkiye'de Türkçe ve Gürcüce iki dili olarak 2007 yılının Temmuz ayında yayınlanmaya başlamıştır. Bu güne kadar 21 sayısı çıkmıştır. Son sayısı 2010 yılında çıkmış ve ekonomik sebeplerden dolayı yayınlanması sona ermiştir. Bu dergide diğer iki kültürel dergi gibi Gürcü dili, Gürcü edebiyatı, Gürcü kültürü, Gürcü sanatı, Gürcü tarihi gibi birçok alana özgü konular yer almaktadır.

\section{Mikheil Cavahishvili’nin yaşamı ve eserleri}

Gürcü düzyazı kurucularından Mikheil Cavakhişvili devrim öncesi yazarlardan biridir. 1880 yllında Gürcistan'ın Kvemo Kartli bölgesinde yer alan Borçalı bölgesinin Tserakvi köyünde doğmuştur. Türklerin yoğunlukla yerleştikleri arazileri Borçalı diye adlandırılır. Resmi olarak Aşağı Kartli diyarı da denen ve çoğunluğunu Azeri Türklerinin oluşturduğu bir bölgedir.” (Memmedli ve Gocaeva Memmedova, 2012: 28). 7 yaşında okula başlayan, eğitimini Rusça alan Mikheil, anadili Gürcü olmayan bir ortamda büyüdüğü için Gürcüceyi tamamen unutmuştur. 13 yaşındayken babası onu Kırım Tarım Okulu'na kaydettirmişti. Ailesi Tserakvi'den Sion Köyü’ne taşınmış ve 5 yll sonra büyük bir acı yaşamıştır. Mikheil'in kardeşini kaçırmaya gelen haydutlar, annesini ve kız kardeşini öldürmüşlerdir. Babası da 1 yıl sonra bu felakete maruz kalmıştır. Cavakhişvili yaşadığı bu üzüntüden dolayı eğitimini yarıda bırakmıştır. Böylece Kırım’dan ayrılmış ve anavatanına geri dönmüştür. Ancak kız kardeşi ile birlikte kaldı $\breve{g}$ Alaverdi'deki kanlı eve ve korkunç köye dayanamamıştır. Rusçaya tamamen hâkim olan Cavakhişvili, zamanla Gürcüceyi kullanmaya başlamış; bu dillerin yanı sıra Azeri Türkçesi, Farsça ve Fransızca da öğrenmiştir.

1901 yllında Gürcistan’a dönen Cavakhişvili ilk hikâyesi Rs6Røy̆s / Çançura’yı (Dilsiz Çançura) 1903

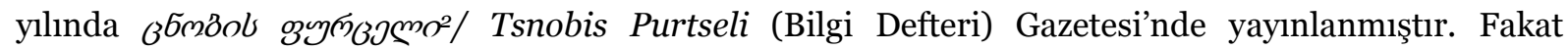

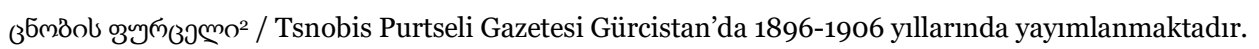

Adres

Kırklareli Üniversitesi, Fen Edebiyat Fakültesi, Türk Dili ve Edebiyatı Bölümü, Kayalı Kampüsü-Kırklareli/TÜRKIYE e-posta: editor@rumelide.com
Adress

Kurklareli University, Faculty of Arts and Sciences, Department of Turkish Language and Literature, Kayalı Campus-Kırklareli/TURKEY e-mail: editor@rumelide.com 
yetkililerin baskına maruz kalmış ve yurt dışına sürülmüştür. Sürgün olduğu dönemlerde Fransa'daki Sorbonne' da derslere girmiştir. Almanya, İtalya ve İsviçre'de bulunmuştur. 1909 yılında ülkesine tekrar dönmüş, ancak vatansever düşüncelerinden dolayı tutuklanmıştır. Daha sonra 1923 yllında serbest kalmıştır. 1937 yılında ise trajik bir biçimde vefat ederek hayatı son bulmuştur.

Mikheil Cavahişvili’nin yapıtlarında Fransız edebiyatı geleneğinin (Zola, Maupassant) etkisi de görülmektedir. Erken dönem öyküleri 1903-1906'lı yıllarda basılmıştır. Daha sonra 1923 yılına kadar kesilmeyen bir "yazınsal sessizlik" dönemine girmiştir. Kısa süre içinde etkileyici ve yüksek düzeyde öyküler ve romanlar yayımlamıştır. Eserleri Rusçaya, Ukraynacaya ve Azerbaycan Türkçesine

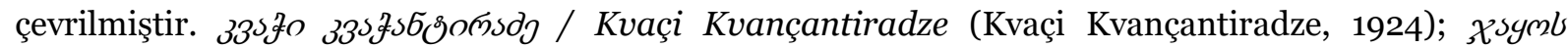

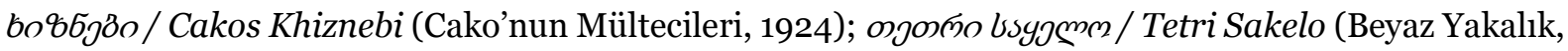

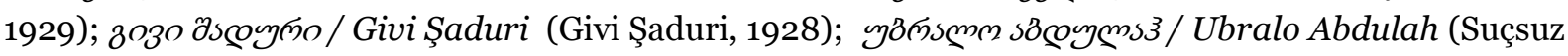

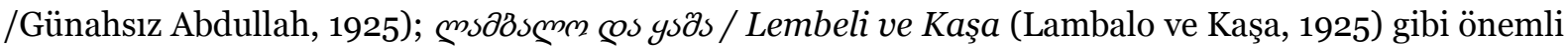

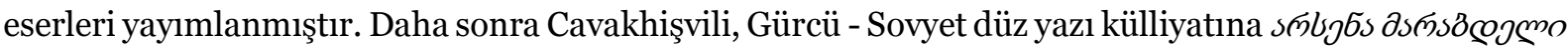
/ Arsen Marabdali (Arsen Marabdali, 1933) bir başka tarihsel roman daha eklemiştir. Mikheil Cavakhişvili'nin, 1905 devriminde Gürcü halkın kahramanca mücadelesini betimlediği son romanı

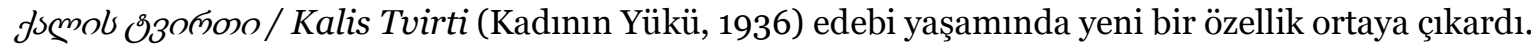

\section{"Suçsuz Abdullah" adlı eserin özeti}

1920'li yılların Gürcü edebiyatında Mikheil Cavakhişvili’nin Suçsuz/Günahsız Abdullah gibi bir eserin varlığı büyük önem taşımaktadır. Eser dikkat çekici bir konuya sahip olmasının yanı sıra çeşitli sanatsal özellikleri de haizdir. Romanın ana karakteri Abdullah'tır. Hikâye Borçalı3'da geçmektedir. O içinde yaşadığı dünyada mutlu olan ilkel, düşünceli, dürüst, açlk yürekli, çalışkan ve güçlü ruha sahip bir insandır. Annesini, eşini ve çocuklarını çok sever. Kendine ait bir çiftliği vardır. Fakat bir gün kuzeninin işlediği bir suçtan dolayı haksız yere hapse atılır. Hapishane ise ailesinin yok edilmesi için bir sebep olur. Adaletsizlik, onun yaşam arzusunu kaybettirir ve iradesini de sarsar. Hayalleri yıkılır, geleceğe karşı inancını yitirir. Sonunda hapishaneden kaçar, karısının ve oğlunun onu terk ettiğini ve evinin barkının yıkıldığını öğrenir. Bundan dolayı kuzeni Mustafa’yı ve ailesini öldürür, hapishaneye tekrar geri döner ve sonunda şaşırtıcı bir şekilde de beraat eder.

Ailesini ve sevdiklerini kaybetme acısı Cavahişvili'nin kalbinde derin bir yara bırakmıştır. Yazar da Suçsuz Abdullah gibi ailesini kaybetme hissi yaşamıştır. Sonuç olarak, bu hikâye, birçok eserde olduğu gibi yazarın kendi gözüyle başından geçen olayı edebi yaratıcılığıyla anlattığı bir eserdir.

\section{Mikheil Cavakhişvili’nin “Suçsuz Abdullah” adlı eserin Türkçeye Tercümesinde kelime ve ifadeler}

Mikheil Cavakhişvili’nin Suçsuz Abdullah adlı hikâyenin yayınları birkaç tanedir. İlk olarak kitapta 1926 yılında yayımlanmıştır. Bu çalışmada, 1925 ve 2011 yılı basımları ele alınacaktır. Kaynak metin-1

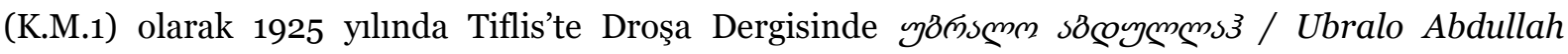

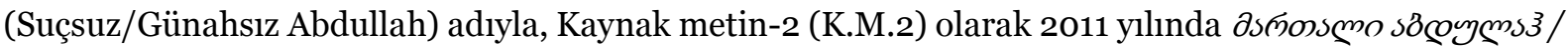
Martali Abdulah (Suçsuz /Günahsız Abdulah) adıyla Tiflis'te yayımlanan metin; Hedef metin (H.M.) olarak ise 1988 yılında İbrahim Yavuz Goradze tarafından "Suçsuz Abdullah" olarak Türkçeye çevrilip

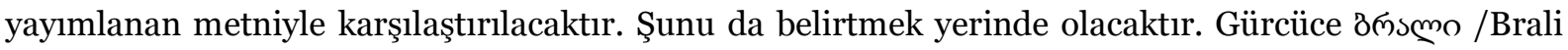

3 Borçalı, Gürcistan'ın Kvemo Kartli bölgesinde yer alan tarihsel bir yerin adıdır. Borçalı bölgesinin esas kısmı bugün Rustavi merkezli Kvemo Kartli bölgesine, kalan toprakları da Kaheti bölgesine bağlıdır. 
Word and expression choice in the translation of Mikheil Cavahishvili's work titled "Suçsuz Abdullah" into Turkish / G. M. Öztürk (pp. 494-511)

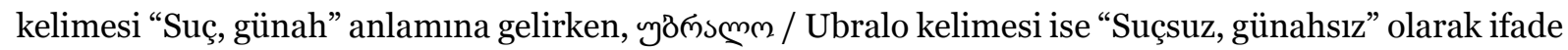
edilmektedir. Günümüz Gürcücesinde "эz̋̋smm / Ubralo" kelimesi daha çok "sade, basit" anlamlarında kullanılmaktadır. Azerbaycan Türkçesine bu hikâye Günahsız Abdulla şeklinde tercüme edilmiştir. Bu karşılaştırmada bazı kelime ve ifadelerin Türkçeye nasıl aktarıldığına değinilecek; böylece Türkçe ifade ve kelimelerin, hedef metne nasıl aktarıldı̆̆ı gösterilmiş olacaktır.

\section{Örnek: 1}

\section{Kaynak Metin 1:}

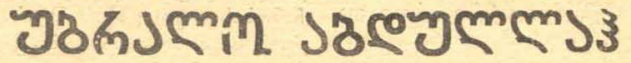

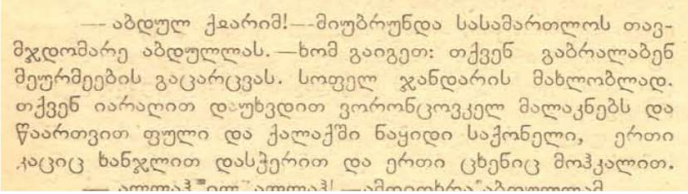

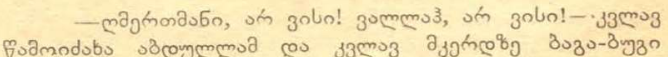
200000.

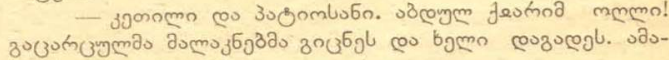
कy mugul osyzon?

\section{Kaynak Metin 2:}

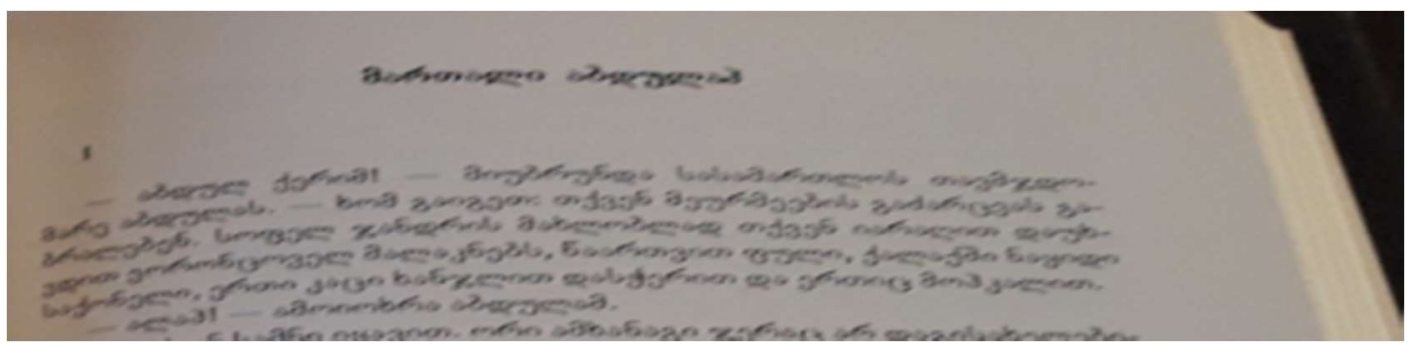

\section{Hedef Metin}

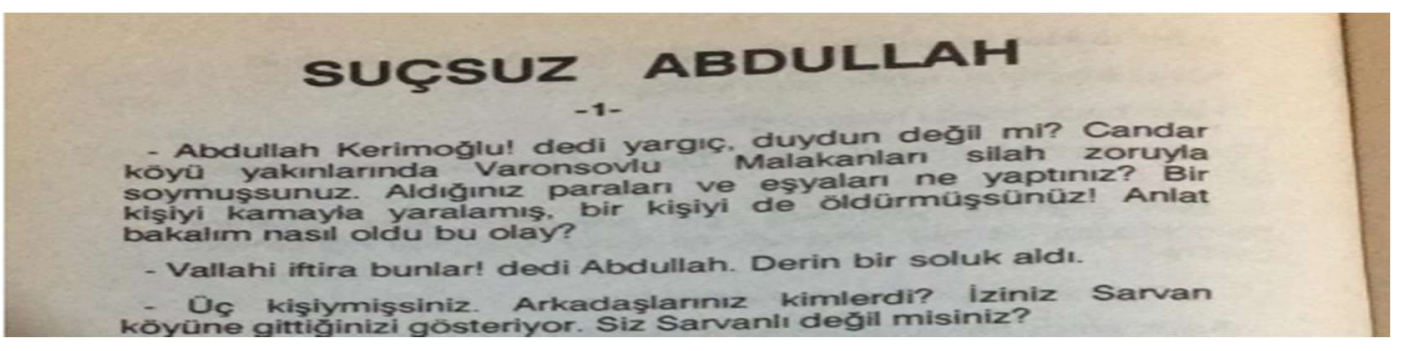

Yukarıda verdiğimiz kaynak metinlerin başlıklarını ve çeviri metnin başlığıyla karşılaştırdığımızda kaynak metin yazarlarının ve çevirmenin farklı tercihlerde bulunduğu göze çarpmaktadır. K.M.1'deki øßnsımm / Ubralo kelimesi Türkçede "suçsuz, masum, sade", K.M.2'de dsફnossmo / Martali kelimesi ise "doğru, gerçek, hakikat, dürüst” sözcükleri ile karşllanır. H.M'de "suçsuz” şeklinde çevrildiğini görmekteyiz. Diğer yandan

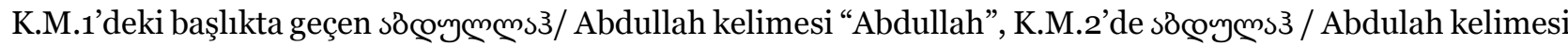
"Abdulah" şeklinde geçmektedir. Ancak H.M.'de ise bu ifade "Abdullah” olarak aktarılmıştır. Buradan

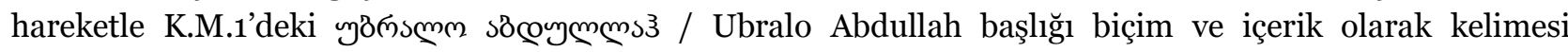

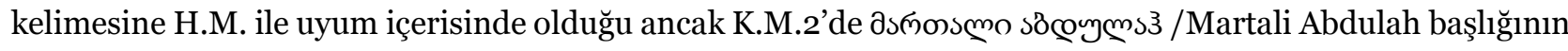
ise biçim olarak farklı olduğu, fakat içerik bakımından esere uyum sağladığı görülmektedir. Şunu da belirtmek gerekirse Mikheil Cavahişvili’nin kaleme aldığı eserin orijinali, 1925 yılında Sovyet döneminde œ̣๓məð১s / droşa 
(Bayrak) dergisinde yayımlanmıştır. Sovyet döneminde yayımlanan eserlerin çoğu daha doğrusu 1925 yılından sonra yayımlanan eserlerde de birtakım çıkartmalar ve eksiltmeler yapılarak redakte edilmiştir. Yani orijinal eserlerin birebir aktarılmadığını söyleyebiliriz. Böylece yukarıda verdiğimiz 1925 yılındaki orijinal metnin aslında hedef metinle birebir uyuştuğu fakat 2011 yılı basımı ile ele aldığımızda bazı farklılıkların olduğunu görmekteyiz. Orijinal eser dergide basıldığı için o dönem redakte edildikten sonra başlıkta da içeriğe ve Gürcü diline uyumlu olması adına değişikliğe gidildiğini de söyleyebiliriz. Bu yüzden hedef metin yazarının daha çok K.M.2’yi göz önüne alarak bir çeviri anlayışı güttüğü açıkça ortadadır. H.M. yazarı, "Suçsuz Abdullah” başlığını kullanarak hikâyenin olay örgüsünden etkilenerek böyle bir çeviri yapmayı uygun görmüştür.

\section{Örnek: 2}

\section{Kaynak Metin 1:}

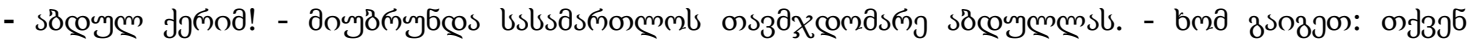

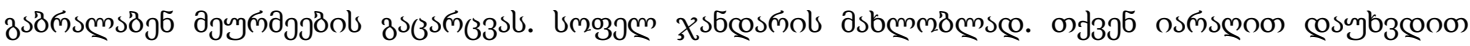

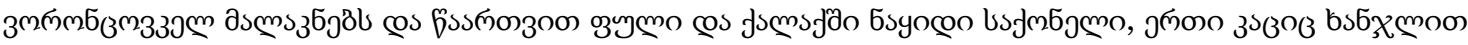

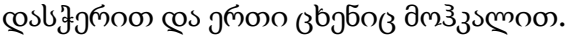

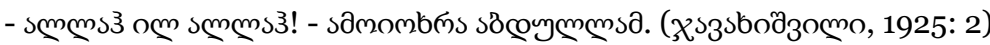

\section{Kaynak Metin 2:}

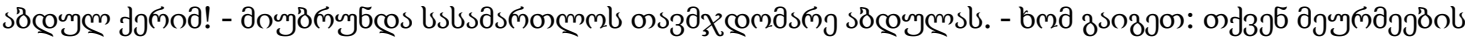

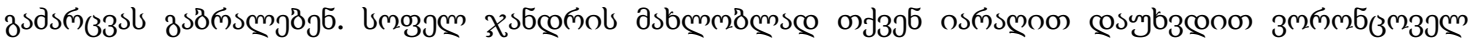

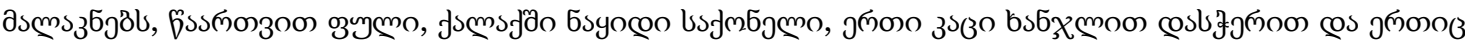
дмзззммоо.

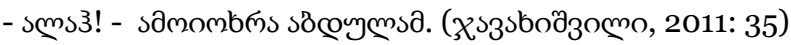

\section{Çeviri Metin (1988 yılı basım)}

-Abdullah Kerimoğlu! Dedi yargıç, duydun değil mi? Candar köyü yakınlarında Varonsovlu Malakanları silah zoruyla soymuşsunuz, Aldığınız paraları ve eşyaları ne yaptınız? Bir kişiyi kamayla yaralamış, bir kişiyi de öldürmüşsünüz! Anlat bakalım nasıl oldu bu olay?

- Vallahi iftira bunlar! dedi Abdullah. Derin bir soluk aldı. (Goradze, 1988: 79).

Yukarıdaki örnekleri incelediğimizde eserin Gürcü harfli ilk basım K.M.1'de smmsß om smmsß̋/ Allah İl Allah

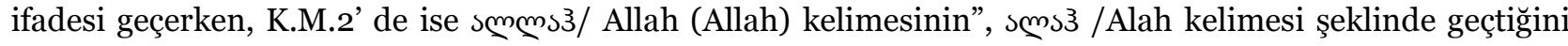
görmekteyiz. Buradan hareketle kaynak metinler arasında da bir farklılığın söz konusu olduğu aşikârdır. Yukarıda da bahsettiğimiz gibi bu, Sovyet dönemindeki yayım eğiliminden kaynaklanan bir durumdur. H.M.'de ise kelimenin "Vallahi” şeklinde çevrildiğini görmekteyiz. Ancak her iki kaynak metinde de bu ifadeyi

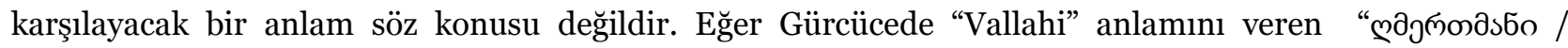
ğmertmani ifadesi kullanılsaydı o zaman hedef metnin yazarının kullanmış olduğu ifade birebir kaynak metinlerdeki anlamı yakalamış olacaktı. Bundan dolayı çevirmen farklı bir ifadeyle kaynak metni aktarmayı tercih etmiştir. Çevirmenin K.M.2'yi göz önüne alarak çevirdiğini düşünürsek K.M.2'de geçen sms3 / Alah (Allah) ifadesini H.M’de ”Vallahi” olarak çevirmesi, eşdeğerlik açısından uygun değildir. 
Word and expression choice in the translation of Mikheil Cavahishvili's work titled "Suçsuz Abdullah" into Turkish / G. M. Öztürk (pp. 494-511)

\section{Örnek: 3}

\section{Kaynak Metin 1}

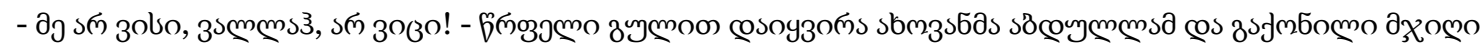

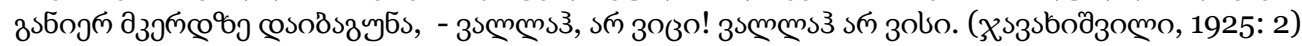

\section{Kaynak Metin 2}

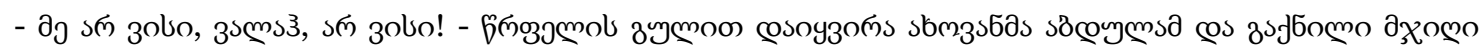

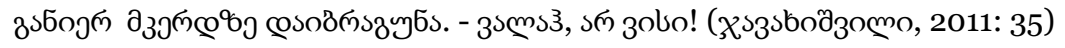

\section{Çeviri Metin}

- Vallahi ben bilmiyorum, vallahi haberim yok bu işten! diye bağırıyordu Abdullah ve bir yandan da göğsünü yumrukluyordu. Vallahi haberim yok! (Goradze, 1988: 79)

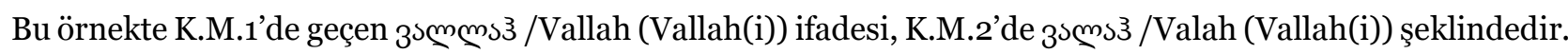
H.M' de ise "Vallahi” şeklinde çevrilerek birebir çeviri stratejisiyle eşdeğerlik sağlanmıştır. İlk yayımlanan eser olan K.M.1'de 3 smms 3 /Vallah (Vallah(i)) kelimesi hem söyleniş hem de biçim olarak Türkiye Türkçesiyle uyum sağlamasına rağmen, K.M. deki Gürcüce aktarımında dilsel düşmelerin olmasından dolayı 3 sms३ß/ Valah (Vallah(i)) şeklinde görmekteyiz. Aslında bu, yanlış bir çeviri/tutum değildir. Çünkü Gürcü dilinin hem sesbilgisel hem de anlamsal değişiklikler görülebilen kendine has bir yapısı vardır. Ses değişikliklerinde ve ortaya çıan ses olaylarında Gürcücenin kurallarının işletildiği ve açıklanabilir değişimler ortaya çıkmaktadır.

\section{Örnek: 4}

\section{Kaynak Metin 1}

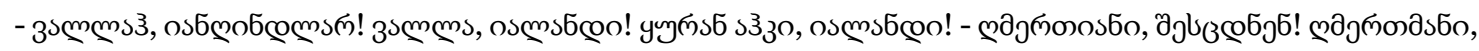

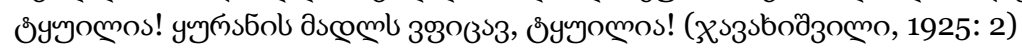

\section{Kaynak Metin 2}

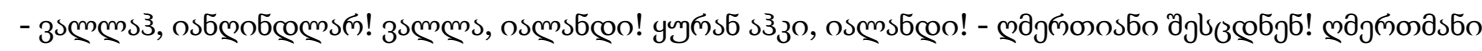

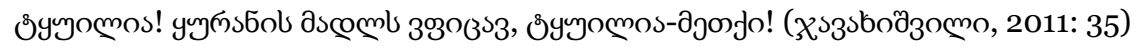

\section{Çeviri Metin}

- Vallahi yalan söylüyorlar, Kuran hakkı için yalandır! (Goradze, 1988: 79)

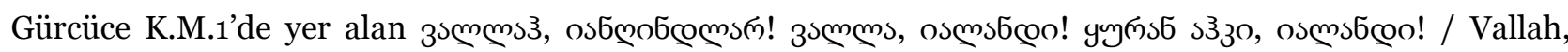
yanğindlar! Valla, ialandi! Kuran ahki, ialandi (Vallah, Yanğindilar! Valla, yalandı! Kuran hakkı için, yalandı!) K.M.2'de de aynı şekilde belirtilmiş olup H.M.'de ise "Vallahi yalan söylüyorlar, Kuran hakkı için yalandır!"

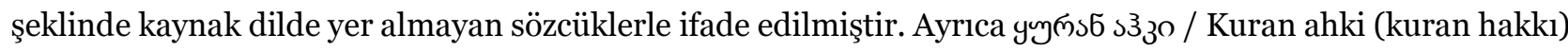
ifadesinde ise K.M. yazarının kelimeyi anladığı ilk şekliyle yazıya döktüğü için bir söz konusu kelime farklı bir sözcükle karşılanmıştır. Fakat bu Türkçe ifadelerin Gürcüce eserde geçmesi ayrı bir öneme sahip olduğu için aktarımda ufak hataların olması kaçınılmazdır. 


\section{Örnek: 5}

\section{Kaynak Metin 1}

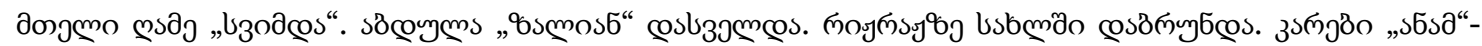

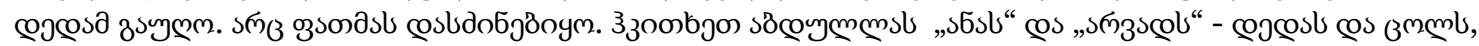

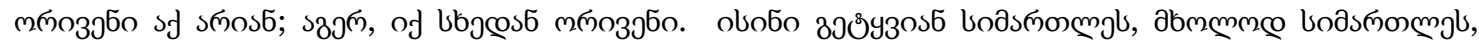

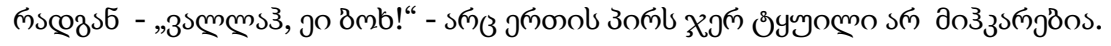

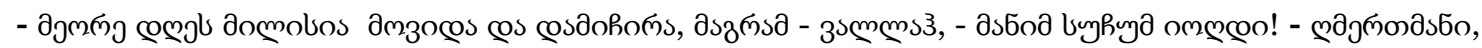

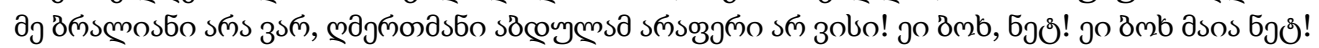

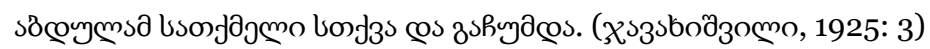

\section{Kaynak Metin 2}

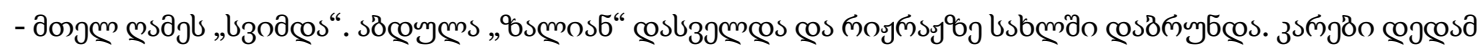

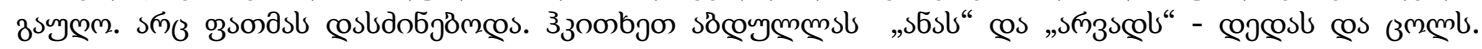

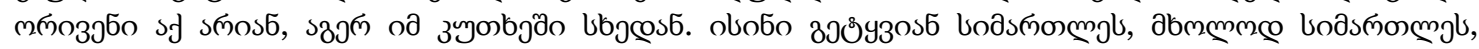
зобsо@ 35 -

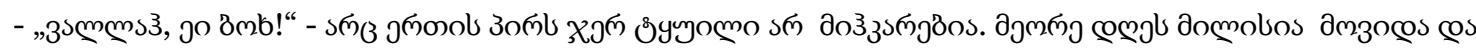

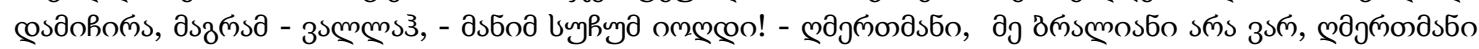

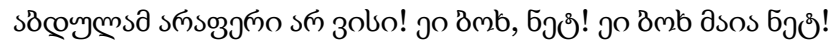

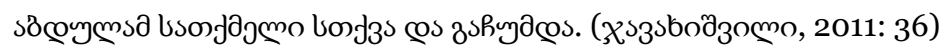

\section{Çeviri Metin}

O gece yağmur yağıyordu. Sırıl sıklam, ancak sabaha doğru dönebildim eve. Kapıyı annem açtı., karım Fatma da uyanıktı. Sorun isterseniz, ikisi de buradalar. Gerçeği söylerler. Vallahi yalanım yok. Sabahleyin polis geldi ve beni tutukladı, oysa benim suçum yok. Vallahi suçsuzum. (Goradze, 1988: 80)

Yukarıdaki örneklerde görüldüğü gibi, K.M.'lerde Gürcüce olarak belirtilen ifadeler H.M' de farklı şekildedir ve bazı yerler çevrilmemiştir. Yukarıda da belirttiğimiz gibi amacımız ilk olarak kaynak metinlerin farklılıklarını ortaya koyarak ve çevirmenin daha çok K.M.2'yi göz önünde bulundurmasından yola çıkarak bir çıkarım yapmaktır. Bu verilerden yola çıkarak K.M.1 ile K.M.2 arasında bir farklılık söz konusu değildir. Kaynak metnin yazarı, eserin konusu Borçalı'da geçtiği için Azerbaycan Türkçesiyle Gürcüce harflerle yazmış ve Gürcüce kelimeleri ise daha çok Azerbaycan Türkçesi’nde yer almayan harflerle doğrudan okunduğu gibi

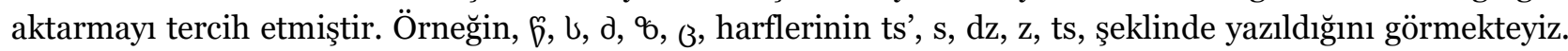
Kaynak metinde yer aldığını görmekteyiz. Bunlara örnek verecek olursak;

\begin{tabular}{|c|c|c|c|c|}
\hline K.M.1 & K.M.2 & $\begin{array}{l}\text { Türkçe } \\
\text { Anlamı }\end{array}$ & Gürcüce Anlamı & H.M \\
\hline ৮3odes / svimda & ৮зодœs/svimda & $\begin{array}{l}\text { yağmmur } \\
\text { yağıyordu }\end{array}$ & 63odcos/tsvimda & yağmur yağıyordu \\
\hline Osmos / zalian & 'ssmos6 / zalian & Çok/fazla & dsços 6 / dzalian & sirll sıklam \\
\hline 3olo / visi & 3olo / visi & Biliyorum & $3^{\circ} 3^{\circ} /$ vitsi & Çevrilmemiştir \\
\hline
\end{tabular}


Word and expression choice in the translation of Mikheil Cavahishvili's work titled "Suçsuz Abdullah" into Turkish / G. M. Öztürk (pp. 494-511)

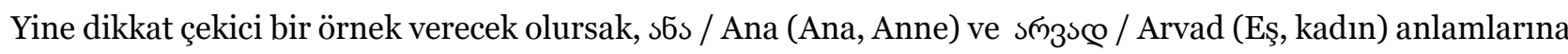
gelen ifadelerinin K.M.1 ve K.M.2'de farklılık söz konusu olmadan yer aldığını görmekteyiz. Azerbaycan Türkçesi’nde arvad, həyat yoldaşı: karı anlamına gelirken, ana: anne anlamına gelmektedir. H.M. bu ifadeleri birebir aktarmayı tercih ederek K.M’nin anlamını yakalamıştır. Her iki kaynak metinde geçen 3 smm

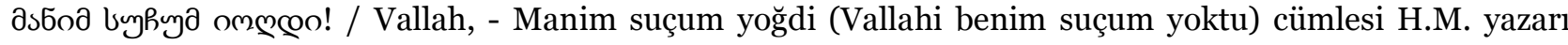
"benim suçum yok" şeklinde kelimesi kelimesine çevirerek aktarmayı tercih etmiştir.

\section{Örnek: 6}

\section{Kaynak Metin 1}

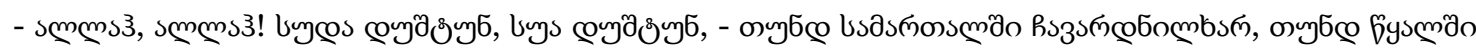

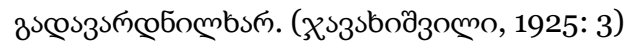

\section{Kaynak Metin 2}

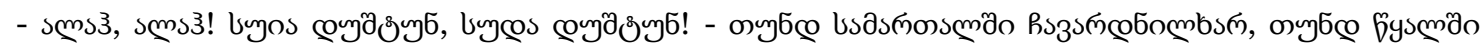

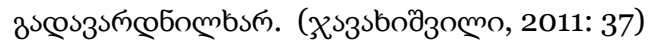

\section{Çeviri Metin}

- Vallahi benim bir suçum yok! İnsan mahkemeye düşeceğine denize düşüp boğulsa daha iyi olur. (Goradze, 1988: 81)

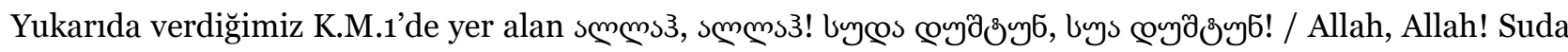

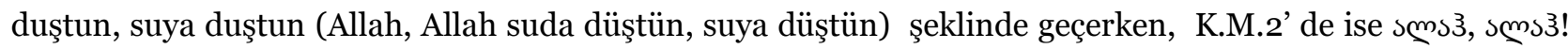

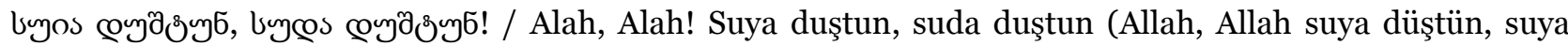
düştün) şeklinde görmekteyiz. İki kaynak metin arasında sadece diller arası farklılıktan dolayı değişiklik vardır. "Suda düştün, suya düştün" ifadesi Borçalı ağzında etken bir deyimdir. "Sud" kelimesi Rusçada "mahkeme" anlamına gelmektedir. Deyimin anlamı ise "Mahkemeye işin düştüyse, suda akıp giden gibisin." şeklinde açıklanabilir. Bir diğer dikkat çekici örnek, K.M.1'de smemsß /Allah (Allah) ifadesini de K.M.2'de s mş3 /Alah (Allah) şeklinde görmekteyiz. Tüm bu veriler ışı̆̆ında verdiğimiz örneği H.M. açısından incelediğimizde çevirmenin doğrudan çeviri işlemi uyguladığı görülmüştür..

\section{Örnek: 7}

\section{Kaynak Metin 1}

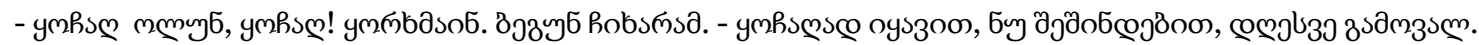

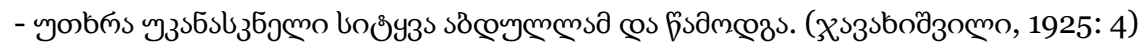

\section{Kaynak Metin 2}

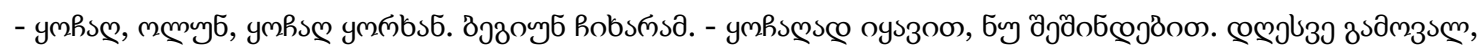

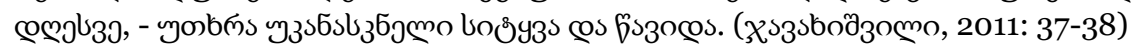

\section{Çeviri Metin}

-Korkmayın, bugün çıkarım, dedi. (Goradze, 1988: 81-82) 
Yukarıda verilen her iki kaynak metin arasında sadece bir noktada farklılık vardır. Örneğin: K.M.1'de ymßsœ

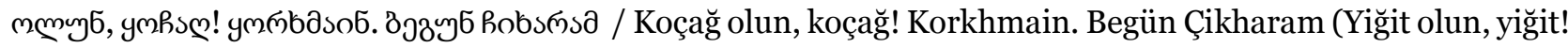

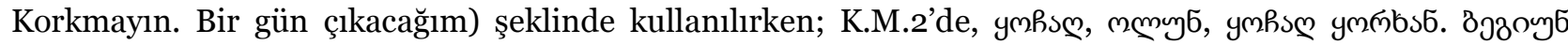
Robsmsa / Koçağ olun, koçağ! Korkhan. Beigün Çikharam (Yiğit olun, yiğit! Korkmayın. Bir gün çıkacağım) şeklinde yer almaktadır. İki kaynak metin arasındaki tek fark K.M.1'in yukarıdaki örneklerde de belirttiğimiz gibi yazarın ilk ağızdan yani ilk basımından doğrudan aktardığı için K.M.1'de ymmbəsıob / Korkhmain (Korkmayın) ifadesini K.M.2'de ymø̋bs6 / Korhan (Korhan) şeklinde redakte etmiş gibi düşündürmektedir. Çünkü konunun akışına bakılırsa "Korkmayın" ifadesi tam olarak hangi cümle yakın ilişkilidir. H.M.' de ise "Korkmayın" şeklinin çevirmen tarafından verildiğini görmekteyiz. Ancak çevirmenin K.M.1 basımından mı ya da K.M.2 basımından mı yola çıkarak yoksa cümlenin akışından dolayı mı bu şekilde çevirdiği konusunda bir takım sorular akla gelmektedir. Aslına bakılırsa son belirttiğimiz cümlenin akışından yola çıkarak çevirdiğini düşünebiliriz çünkü ilk basımı Sovyet zamanında yayımlanmıştır. 1925 yılından sonra çıkan basımları ise redakte edilerek basılmıştır. Piyasada daha çok 1925'den sonraki basımları ele alınmıştır.

\section{Örnek: 8}

\section{Kaynak Metin 1}

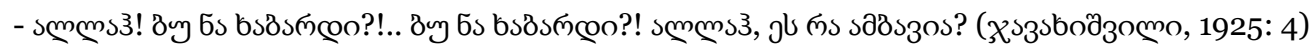

\section{Kaynak Metin 2}

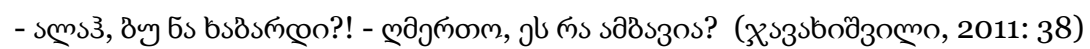

\section{Çeviri Metin}

- Aman tanrım bu nedir! dedi. Dudakları titriyordu. (Goradze, 1988: 82)

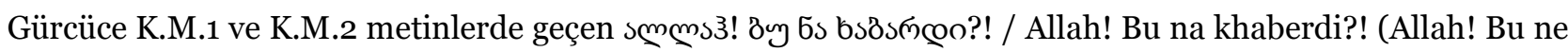
haberdi?!) ifadesinde K.M.2'de bir farklılık söz konusudur. Şöyle ki, smmş / Allah (Allah) ifadesi sms3 / Alah (Allah) şekliyle geçmektedir. Burada yanlışlık yoktur. Sadece redakte sırasında Gürcüceye aktarılırken m (L): L harfi düşerek smsıß / Alah şeklinde kullanılmıştır. Çünkü özel isimlerde sessiz harfler çoğunlukla yan yana kullanılmadığı için böyle bir kullanım söz konusudur. Kaynak metinlerde geçen bir diğer örnek ise

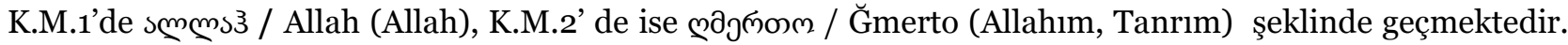
Bu yüzden kaynak metinler arası farklılık vardır. Yazarın ilk basımında smms३ / Allah (Allah) ifadesi diğer

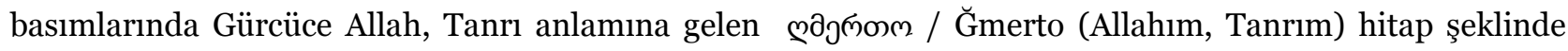
aktarılma söz konusudur. Aslında orijinal harfli ilk basımına bağlı kalarak aktarılsaydı eserin konusu itibariyle daha anlamlı olacaktı. Ama genel olarak Sovyet döneminde eserlerin basımında bir takım değişiklikler yapıldı̆̆ı için K.M.2'deki ifadeyi Gürcü dilinde kullanıldı̆̆ı şekliyle görmekteyiz.

\section{Örnek: 9}

\section{Kaynak Metin 1}

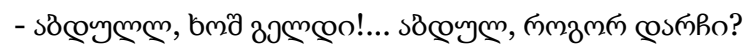

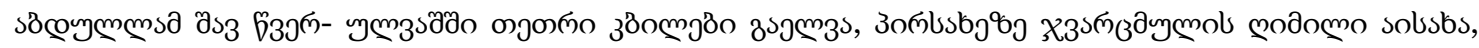

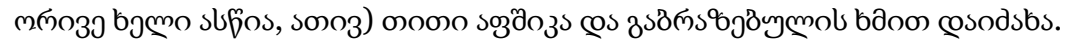


506 / RumeliDE Journal of Language and Literature Studies 2020.18 (March)

Word and expression choice in the translation of Mikheil Cavahishvili's work titled "Suçsuz Abdullah" into Turkish / G. M. Öztürk (pp. 494-511)

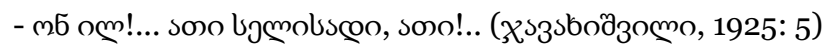

\section{Kaynak Metin 2}

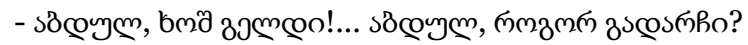

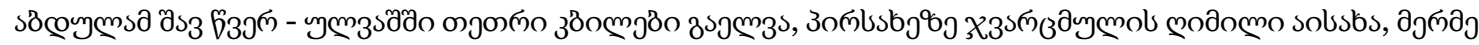

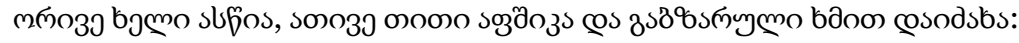

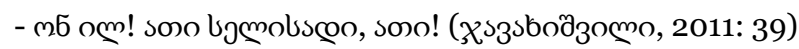

\section{Çeviri Metin}

- Hoş geldin Abdullah! Nasılsın bakalım? Ne var ne yok? dediler.

Abdullah kapkara sakallarının ve bıyıklarının arasından beyaz dişlerini göstererek gülümsedi, yüzünde bir gülümseme vardı. İki elini kaldırarak:

-Hiçbir suçum yokken on yıla mahkum olduk! On yıl ceza yedik! Allahtan reva mıdır bu da! Hiç insaf ve merhamet kalmamış bu dünya da! dedi. (Goradze, 1988: 83)

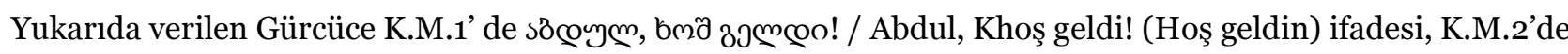

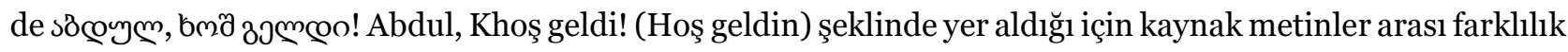
yoktur. Çevirmen "Hoş geldin Abdullah!" şeklinde aktararak kelimesi kelimesine çeviri uygulayarak hedef metne aktarmayı başarabilmiştir. (Geldi-a (зэmœo-s) < geldi: Geldi.) Kaynak metinlerde geçen bir diğer örnek ise, "On yıl” anlamına gelen K.M.1 ve K.M.2'de $m 5$ om! / On il (on yl) şeklinde kullanılmasıdır. Bu da metinler arasında farklılığın olmadığını göstermektedir. Çevirmen tarafından hedef metne "on yıl” şeklinde çevrildiğini görülmüştür.

\section{Örnek: 10}

\section{Kaynak Metin 1}

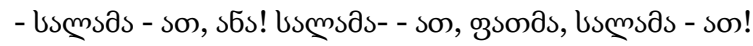

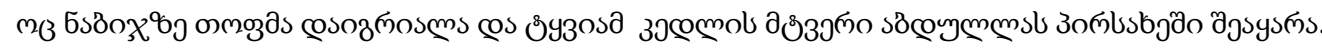

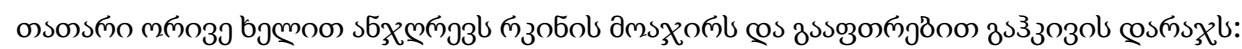

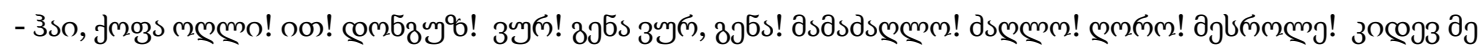

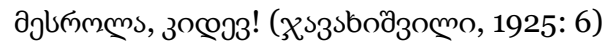

\section{Kaynak Metin 2}

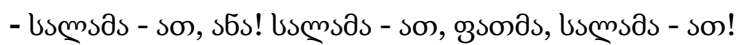

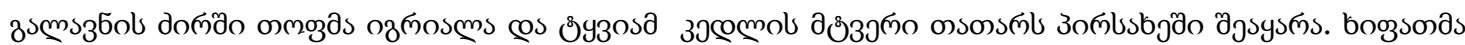

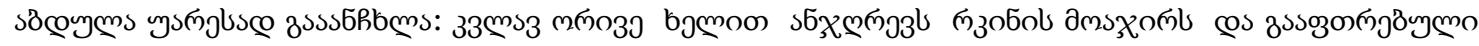

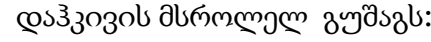

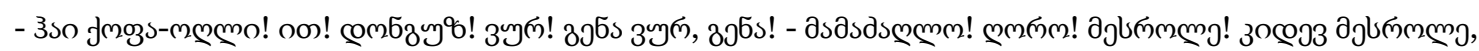

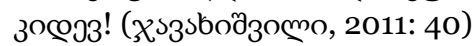

\section{Çeviri Metin}

- Selametle ana!.. Selametle Fatma!.. Selametle... 
Karşılıklı seslenmeler devam edince, nöbetçi kulübesinden atılan kurşunun duvardan kopardığı sıva parçaları Abdullah'ın yüzüne gözüne serpildi. Abdullah’ı daha da öfkelendirdi bu durum. Pencereden iki elini de sallayıp kudurmuş gibi bağırmaya başladı nöbetçiye... (Goradze, 1988: 84)

Bu örnekte, K.M.1' deki ifadede: usmsas - son, sbs! bsmsas - son, øssonds, / Salama-at, ana! Salama-at, patma ( Selamet, Ana! Selamet Fatma) ifadesi kullanılmakla birlikte, K.M.2'de, bsmsas - son, sбs! bsmsas- - son, ossonas / Salama-at, ana! Salama-at, patma (Selamet, Ana! Selamet Fatma) şeklinde bir çeviri kullanılmıştır. Her iki kaynak metinde farklılı yoktur. H.M.' de ise bu ifadeyi "Selametle ana!.. Selametle Fatma!.. Selametle" şeklinde çevirmiştir. Dolayısıyla anlam bütünlüğü bozulmadan aktarılmıştır. Bir diğer dikkat çeken örnek,

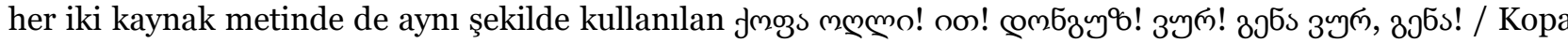
oğli! İt! Donguz! Vur! Gena vur, Gena! (Köpekoğlu! İt! Domuz! Vur! Gene (yine) Vur!, Gene (yine)) kelimelerdir. Bu argo kelimeler hedef metinde de yer almamaktadır yani çevirmen tarafından çevrilmemiştir.

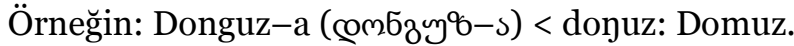

\section{Örnek: 11}

\section{Kaynak Metin 1}

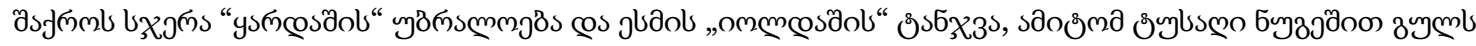

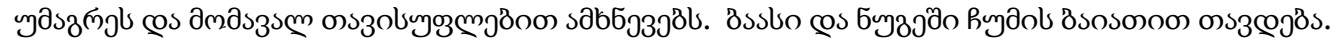

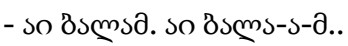

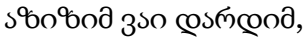

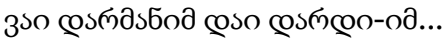

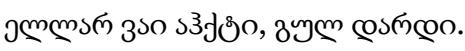

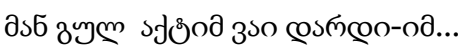

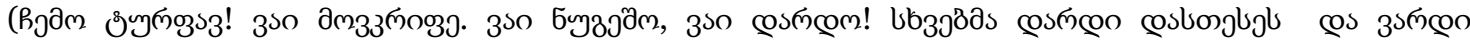

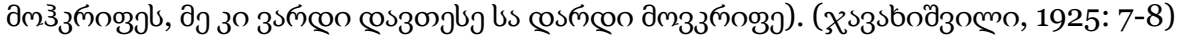

\section{Kaynak Metin 2}

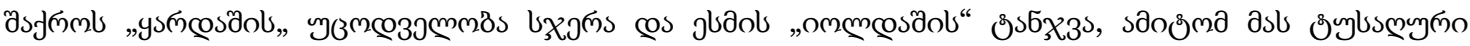

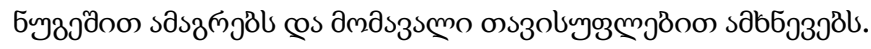

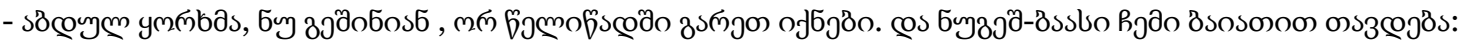

- so Bssmsa, Bssms-s-sa..

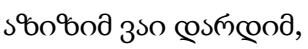

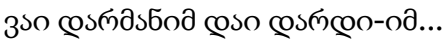

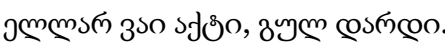

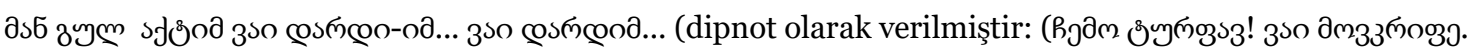

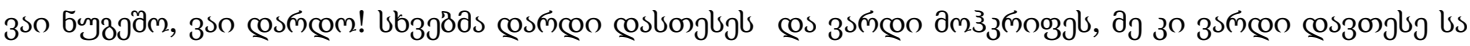

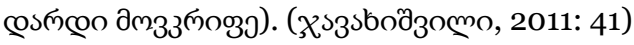

\section{Çeviri Metin}

Şakro da inanıyordu gerçekten bir suçu olmadığına. Bu yüzden her keresinde onu teselli ediyordu:

-Merak etme Abdullah, iki yıl sonra dışardasın! 
Word and expression choice in the translation of Mikheil Cavahishvili's work titled "Suçsuz Abdullah" into Turkish / G. M. Öztürk (pp. 494-511)

Abdullah türkü söylemeye başlıyordu:

Ey balam, balam balaaam!

Ah, benim derdim çok balam!

Ben gül ekerim vay biter!

Balam, balam benim derdim...(Goradze, 1988: 85-86)

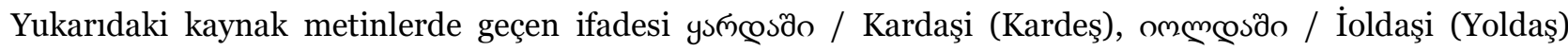
şeklinde kullanılmıştır. Hedef metinde ise bu ifadelerin Goradze tarafından çevrilmediğini görmekteyiz. Ayrıca ele aldığımız bir diğer örnekte geçen türkü, kaynak metinlerde farklı şekillerde yer almaktadır. Tablo şeklinde örnek verecek olursak;

\begin{tabular}{|c|c|c|}
\hline K.M.1 & K.M.2 & H.M \\
\hline 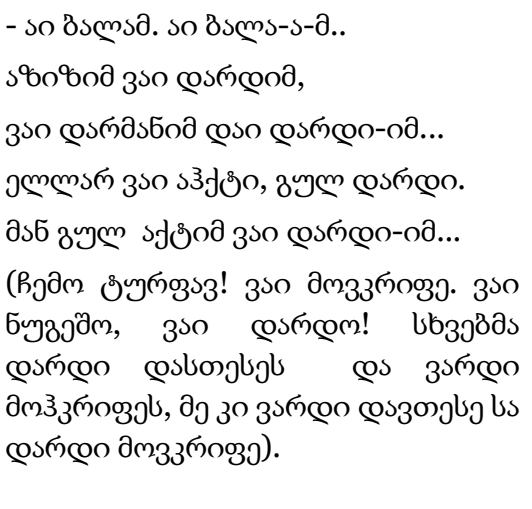 & 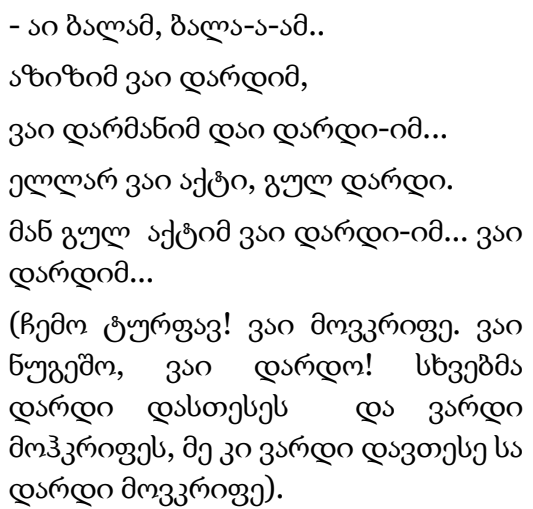 & $\begin{array}{l}\text { Ey balam, balam balaaam! } \\
\text { Ah, benim derdim çok balam! } \\
\text { Ben gül ekerim vay biter! } \\
\text { Balam, balam benim derdim } \\
\text { (Çevrilmemiş kısım var) }\end{array}$ \\
\hline
\end{tabular}

Yukarıda verdiğimiz örnek kaynak metinlere göz attığımızda bir farklılık görülmemektedir. Ancak K.M.2’ de

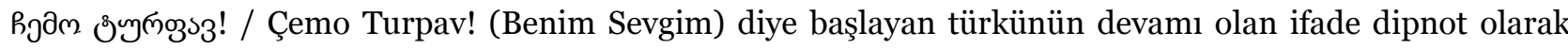
verilmiş olup, K.M.1'de ise dipnot olarak değil doğrudan türkünün devamına ilave edilmiştir. Hedef metinde ise bu türküde geçen ifadeler çevrilmemiş, bazı ifadeler doğrudan çıkarılmıştır. Her iki kaynak metinde geçen Arapça kelime olan ১\%o\%o /Azizi (Aziz/özenli) kelimesi hedef metne aktarılmamıştır. Hedef metinde geçen “çok" ifadesinin karşılayacak kelime kaynak metinlerde yer almamaktadır. Kaynak metinlerde geçen

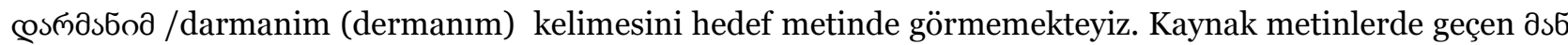

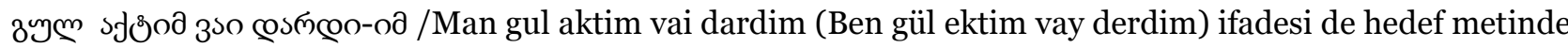
"Ben gül ekerim vay biter!" şeklinde bağımsız bir çeviri ile yapılmıştır.

\section{Örnek: 12}

\section{Kaynak Metin 1}

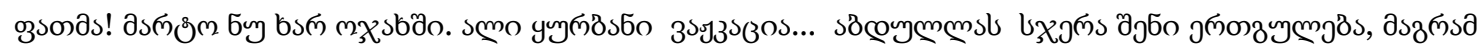

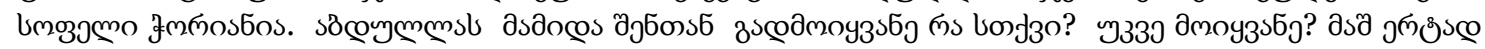

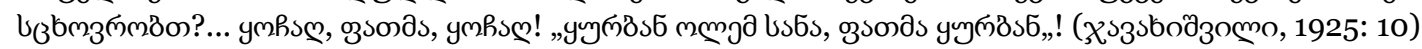

\section{Kaynak Metin 2}

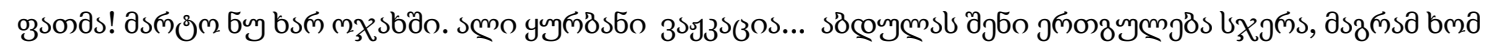

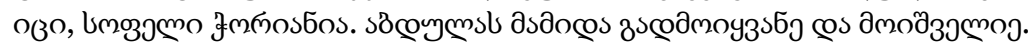




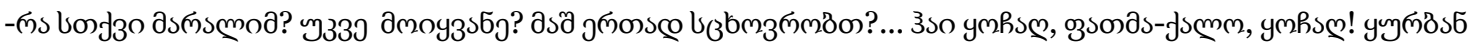

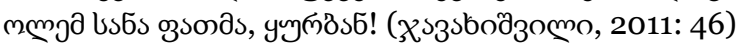

\section{Çeviri Metin}

Fatma, yalnız değilsin. Evimize bak! Ali Kurban var. Babayiğit bir insan, evin işlerini ona yaptırırsın. Senin ciddi ve temiz yürekli olduğunu biliyorum. Fakat köylük yerde dedikodu çoktur. bu yüzden halamı da yanına al birlikte kalın. Olabilirse ben çıkana kadar kalsın yanınızda. O da yardım eder sana.

- Ne dedin sevgilim? Halamı getirdin mi evimize, yanında mı kalıyor şimdi? Birlikte yaşıyorsunuz öyle mi? Aferin karıcığım, aferin sana! Kurban olayım sana! Ne dedin, gitme zamanı mı geldi? Nöbetçi izin ver biraz daha! Ben tümden yetim kaldım burada. Anam ölmüş, bitmedi daha diyeceklerimiz. Daha konuşacaklarımız var! (Goradze, 1988: 91)

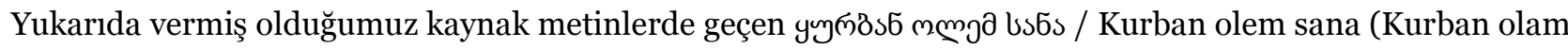
sana) ve дs๓sмnод / Maralim (Güzelim) adlı kelimeler her iki kaynakmetinde de vardır. Bu kelimelerin H.M.

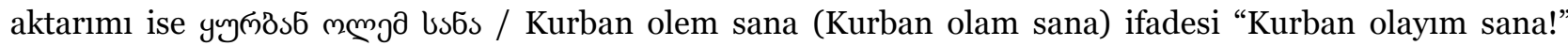
şeklinde yer alırken, д১๓ুsmod /Maralim (Güzelim) kelimesi ise "sevgilim” şeklinde birebir çevrilmiştir.

\section{Örnek: 13}

\section{Kaynak Metin 1}

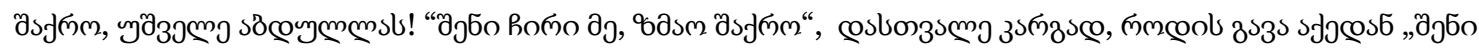

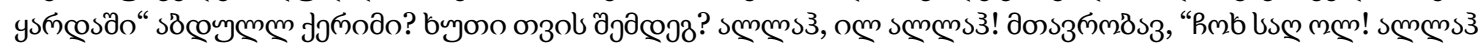

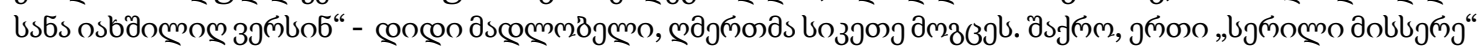

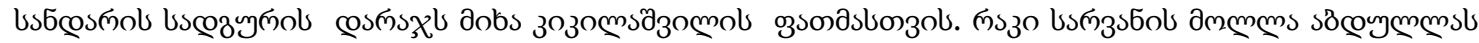

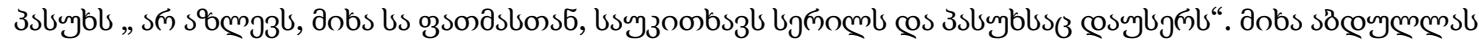

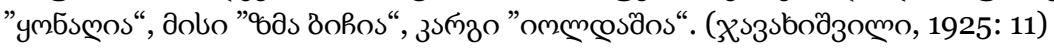

\section{Kaynak Metin 2}

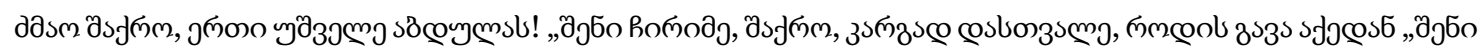

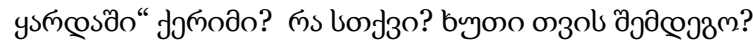

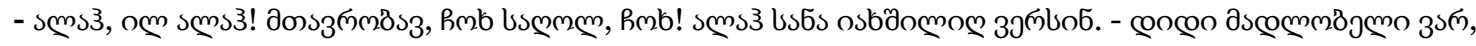

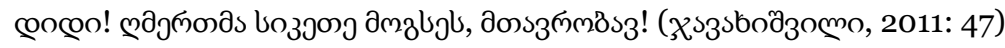

\section{Çeviri Metin}

Çok sağol Şakro’cuğum! Allah razı olsun! Allah zeval vermesin. Hükümetimize, adalete. Yaşasın adalet! diye bağırdı. (Goradze, 1988: 93)

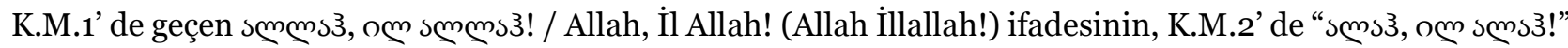
şeklinde yer aldığı görülmektedir. İki kaynak metni incelediğimizde aralarındaki tek farkın, smmsß / Allah (Allah) kelimesi, s msз / Alah (Alah) olduğu görülmektedir. Bu da dillerarası aktarımda her dilin kendine özgü yapısı olduğundan aktarımda da anlamı aynı olsa da yapı ve diziliş bakımından bazı farklılıkların olabileceğini göstermektedir. Burada da aslında sadece Gürcü diline aktarım olduğu için düşme meydana gelmiştir. Ayrıca şunu da belirtmek gerekir ki eserin ilk orijinal halinde bu düşmenin olmamasının sebebi; yazarın, doğrudan dergide olduğu gibi yayımlamasından kaynaklanmaktadır. Aslında orijinal harfli ilk eseri tabii ki de Türkçeye aktarımında birebir uyum sağlamaktadır. Ancak redakte edildikten sonraki aşamada eserin özgün dilinde olduğu için düşmeler meydana gelmektedir. Bir diğer ilginç bulduğumuz K.M.1 ve K.M.2' de yer alan örnek,

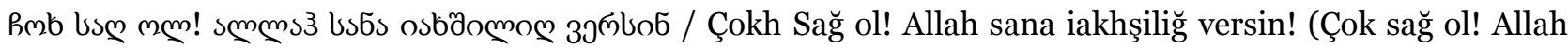


Word and expression choice in the translation of Mikheil Cavahishvili's work titled "Suçsuz Abdullah" into Turkish / G. M. Öztürk (pp. 494-511)

sana iyilik versin) ifadesidir. Öztürk'e göre (2019: 483) "Bmb bsলmme / çokh sağol, Çok sağ ol! Türkçe: Çok

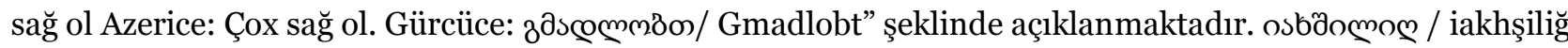
(iyilik) kelimesi ise Türkiye Türkçesi Ağızlar Sözlüğünde yağşı (I). İyi, güzel, değerli. (Derleme Sözlüğü c: 11 ) şeklinde geçmektedir. Buradan hareketle verdiğimiz ifadeyi hedef metinde "Çok sağol Şakro'cuğum! Allah razı olsun! Allah zeval vermesin” şeklinde çevrildiğini görmekteyiz. Hem birebir çeviriyi tercih ederek, hem de "Allah zeval vermesin" ifadesini eklediğini görmekteyiz.

\section{Örnek: 14}

\section{Kaynak Metin 1}

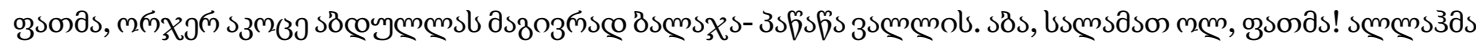

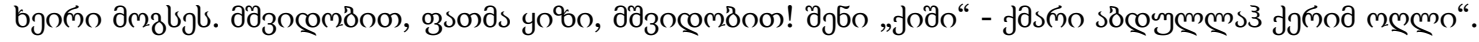

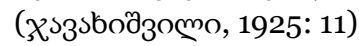

\section{Kaynak Metin 2}

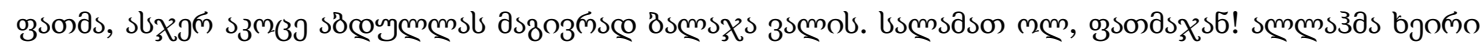

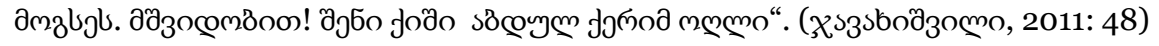

\section{Çeviri Metin}

"Fatma, oğlum Veliyanın gözlerinden öp benim için. Şimdi Tanrı’ya emanet ol Fatmacan! Allahısmarladık." (Goradze, 1988: 93)

Her iki kaynak metin de verilen örneği hedef metinden bağımsız bir çeviri tercih etmiş ve çıkartma işlemi

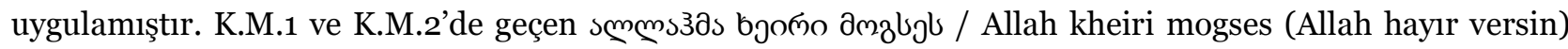

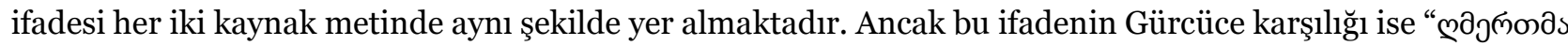

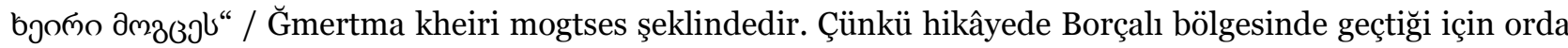
konuşulan dil Azerbaycan Türkçesi olduğu için yazar direkt esere o şekilde yansıtmıştır. Burada dikkat çeken bir diğer nokta bahsettiğimiz örneklerde de yer alan smmsз / Allah (Allah) kelimesinin K.M.2' de doğrudan geçtiğidir. Aslında diğer örneklerde; mesela K.M.2’ ye baktığımızda sçs૩ / Alah (Allah) şeklinde yer alıp “ $m$ / L “ harfi düşmüştür. Ama bu verdiğimiz örnekte böyle bir durum söz konusu değildir. Çünkü kelime direkt olduğu gibi aktarılmıştır. Tüm bunları dikkate aldığımızda hedef metinde bu ifadelerin yer almadığını ve bağımsız bir çeviri anlayışına sahip olduğunu söyleyebiliriz. Yine kaynak metinlerde joð̊o /Kişi (kişi, insan) ve yo\%o / qizi (kız) anlamına gelen ifadelerin de metinde yer aldığı görülmektedir. Ancak çevirmen tarafından bu ifadeye hedef metinde yer "verilmediğini, çevrilmediğini" söyleyebiliriz. Kaynak metinlerde geçen

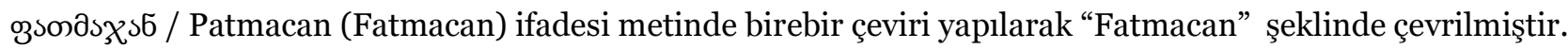

\section{Sonuç}

Ülkeler arasındaki her bağlantı, birbirine farklı izler bırakmaktadır. Bu izler, dilbilimsel araştırmalarda, milletlerin tarihlerini kavramak için, önemli kaynaklardır. Bu ilişkilere dayanılarak kelime hazineleri ve dilbilimsel unsurlar aydınlatılabilmektedir. Kelime alışverişleri sonucunda, zamanla dillerde zengin bir eş anlamlılık ortaya çlkmakta ve ortak bir onomastik alan da oluşmaktadır. Gürcistan ve Türkiye arasındaki bu gibi ilişkiler, yüzyllardır sürmektedir.

Türk-Gürcü uluslarının dil, kültür ve edebi ilişkileri Gürcü yazar "Mikheil Cavahişvili’nin Suçsuz Abdullah Adlı Eserinin Türkçeye Tercümesinde Kelime ve İfadeler” adlı çalışmada Gürcüce yazılmış Türkçe kelimelerin 
eserin tercümesinde nasıl aktarıldığı üzerinde durulmuştur. Bu kapsamda Mikheil Cavahişvili’nin ilk basımı

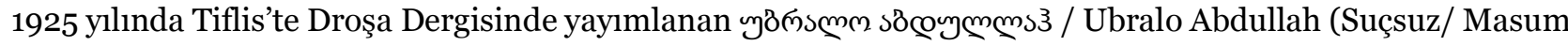
Abdullah) ile Kaynak Metin2 (K.M.2) olarak 2011 yllında dsmonsmo söøyms3 / Martali Abdulah (Suçsuz/Masum Abdullah) adıyla Tiflis'te yayımlanan metinleri, 1988 yllında İbrahim Yavuz Goradze tarafından Türkçeye çevrilip Bursa'da yayımlanan "Suçsuz Abdullah” metniyle karşılaştırılarak ele alınmıştır. İnceleme sırasında kaynak metinden seçtiğimiz örnekler hedef metinle karşılaştırıp incelenmiştir. İnceleme sonucunda eserde geçen Türkçe ifadelerin bazılarının karşılığının tam olarak hedef metne aktarıldığı, bazılarının ise çevirisinin yapılmadığını söyleyebiliriz. Genel itibariyle bakıldığında yer alan Türkçe kelime ve ifadelerin Gürcüce harfleriyle olduğu gibi aktarılması Gürcü ve Türk edebi dil ilişkileri açısından GürcüceTürkçe kelime hazinesi üzerinde belirgin, izlenebilir bir iz bırakmıştır.

Sonuç olarak, Türkçe ile Kafkas dilleri arasındaki ilişkiler hakkında değerli akademik çalışmalar yapılmış ve hâlen yapılmaktadır. Bu kapsamda, Gürcü edebiyatına ait eserlerin incelenmesi büyük önem arz etmektedir. Makalemizin bu yöndeki çalışmalara bir katkıda bulunmasını ümit etmekteyiz.

\section{Kaynakça}

Abuladze, T. (2004). Gürcistan'daki Türkoloji Çalışmaları. Türk Dili, Dil ve Edebiyat Dergisi, Sayı: 650.

Bakhutashvili, M. (2016). Gürcüceye Geçen Türkçe Kelimeler Üzerine Gürcistan'da Yapılan Çalışmalar. (Yayınlanmış Yüksek Lisans Tezi). Anadolu Üniversitesi/Sosyal Bilimler Enstitüsü, Eskişehir.

Benaşvili, D. (1959). Mikheil Cavikhişvili’nin Hayatı ve Edebi Kişiliği. Tiflis: Gürcistan Bilimler Akademisi.

Cavakhişvili, K. (2000). Mikheil Cavikhişvilinin Hayatı ve Edebi Kişiliği. Tiflis: Sabçota Sakartvelo (Sovyet Gürcistan).

Cavakhişvili, M. (1959). Cakos Khiznebi, Seçilmiş Hikâyeleri. Tiflis: Sabçota Sakartvelo (Sovyet Gürcistan).

Cavakhişvili, M. (1969). Kvaçi Kvaçantaridze Seçilmiş Hikâyeleri. Tiflis: Sabçota Sakartvelo (Sovyet Gürcistan).

Cavakhişvili, M. (1973). Seçilmiş Hikâyeleri. Tiflis: Sabçota Sakartvelo (Sovyet Gürcistan).

Cavakhişvili, M. (1977). Seçilmiş Hikâyeleri. Tiflis: Sabçota Sakartvelo (Sovyet Gürcistan).

Cikia, S. (1937). Anadolu Türkçesinin Ahıska (Ahaltsikhe) Ağzında bir Morfoloji Olay Hakkında. TDÜ Çalışmaları. Türk Dili, Dil ve Edebiyat Dergisi, Sayı. 650.

Çiloğlu, F. (1993). Dilden Dine, Edebiyattan Sanata Gürcülerin Tarihi. İstanbul: Ant.

Kaukhchishvili, S. (1955). Kartlis Tskhovreba (Gürcü Yaşamı), Sözlük. Tiflis: El Yazmaları Enstitüsü.

Memmedli, Ş., Gocaeva Memmedova, G. (2012). Gürcistan'daki Borçalı Azeri Türklerinde Âşıklık Geleneği. Turan Stratejik Araştırmalar Merkezi Dergisi, C. 4, 14/4, s. 28.

Öztürk, G. M. (2015). 19. Yüzyll Türk-Gürcü Edebi Etkileşim Süreci. Turkish Studies, International Periodical For The Languages, Literature and History of Turkish or Turkic, 10/4, 773-780.

Öztürk, G. M. (2019). MiKheil Cavahişvili’nin “Lambalo ve Kaşa” Romanındaki Türkçe Kelime ve İfadelerin Incelenmesi. RumeliDE Journal of Language and Literature Studies. Volume: 15, 479-486.

Sağinadze R, Peikrişvili J, Çimke H. (2015). Gürcü Dili. Rize: STS.

Thomson, G. (1966). Marksizm ve Şiir. İstanbul: Uğrak Kitabevi.

Türk Ansiklopedisi (1970). Gürcistan-Gürcüler. Cilt: XVIII, Ankara: M.E.B. 